\title{
Starch-Jute Fiber Hybrid Biocomposite Modified with Epoxy Resin Layer: Fabrication and Experimental Characterization
}

\author{
Akarsh Verma ${ }^{1,2}$, Kamal Joshi ${ }^{2}$, Amit Gaur $^{2}$ and V. K. Singh ${ }^{2}$ \\ ${ }^{1}$ Indian Institute of Technology, Roorkee, India \\ ${ }^{2}$ G. B. Pant University of Agriculture and Technology, Pantnagar, India
}

\begin{abstract}
In this article, bio-composites derived from starch-glycerol biodegradable matrix reinforced with jute fibers have been fabricated using the wet hand lay-up and compression moulding techniques. Samples having different weight percentages of jute fiber in the starch matrix have been analysed. The fibers surface was chemically treated by alkaline sodium hydroxide for improving the interphase bonding between fiber and matrix. Tensile test for the composites were done and the sample with highest tensile strength was selected for further tests that included water absorption, scanning electron microscopy and thermal analysis. It has been concluded that the ultimate tensile strength was found to be maximum for the composition of $15 \%$ fiber by weight composite as $7.547 \mathrm{MPa}$ without epoxy coating and $10.43 \mathrm{MPa}$ with epoxy coating. The major disadvantage of bio-composite is its high water absorption property, which in this study has been inhibited by the epoxy resin layer. Herein, the results of various tests done disclose a noteworthy improvement in the overall properties of bio-composite, in comparison to the neat biodegradable starch matrix.
\end{abstract}

Keywords: Jute fiber, Starch matrix, Epoxy resin, Biocomposite, Microstructure 


\section{Introduction}

A composite is a structural material that consists of two or more combined constituents (matrix and reinforcement) at a macroscopic level and is not soluble in each other. In order to meet the ecological objects, both the matrix and reinforcement need to be fully biodegradable to avoid further annihilation of the environment. Although the presently accessible fully 'Green' composites (biocomposites), do not satisfy all the requirements for automotive components, but they tend to be the subsequent innovational materials in the upcoming future. There is growing urgency to develop and commercialize new crops, new bio-based products and other innovative technology which don't rely on fossil fuel. That's why biocomposites are becoming one of the most important factors in creating a more ecological future.

Bio composites are inexpensive, recyclable, possess low density and high strength to weight ratio [1, 2]. Cao et al. [3] investigated the mechanical properties of biodegradable composites reinforced with untreated and alkali treated bagasse fiber. Mechanical properties of the composite made from alkali treated fibers were superior to the untreated fibers. Approximately $13 \%$ improvement in tensile strength, $14 \%$ in flexural strength and 30\% in impact strength had been found, respectively. Gilfillana $\boldsymbol{e t}$ al. [4] studied the preparation and characterization of composites from starch and bagasse. Different types of tests were conducted on 5 weight percentage (wt $\%), 10 \mathrm{wt} \%$ and $20 \mathrm{wt} \%$ fiber composites which showed different properties. Addition of bagasse fiber significantly impacted on the Young's modulus of the starch films.

Jute is multi-celled in structure and a lingo-cellulosic fiber as its chief chemical ingredients are cellulose and lignin. [5]. It is usually derived from jute plant stem and grows to about 2.5-4.5 metres. Amongst various natural fibers, jute fibers are effortlessly obtainable in fabric forms with decent mechanical and thermal properties [6]. River flats, depressions and saline-alkali soils are most appropriate for the jute plantation [7]. 
Excessive work has been published concerning the reinforcing potential of jute fiber with polymer composites. There are several factors to be considered when designing the composite materials [8]. Gassan and Bledzki [9] calculated the improvement in mechanical properties of jute fibers reinforced thermoset resin composites considering several parameters. Gowda et al. [10] assessed the tensile behaviour of jute-fabric reinforced polyester material in both the longitudinal and transverse directions. Mohanty et al. [11] considered the effect of jute fiber content on the tensile behaviour of jute fabrics-polyester amide composites. Albuquerque $\boldsymbol{e t}$ al. [12] evaluated the effect of fiber surface wettability, alkali treatment and different ageing conditions on the tensile properties of longitudinally oriented jute reinforced polyester composites. Ray et al. [13] investigated the alkali treatment of jute fiber and composites in terms of tensile and flexural properties. Khondker et al. [14] considered the tensile behaviour of unidirectional jute/polypropylene composites fabricated by film stacking method. Cabral $\boldsymbol{e t}$ al. [15] examined the mechanical response, water uptake, and dielectric properties of short jute fiber reinforced polypropylene composites. It was found that the Young's modulus and tensile strength monotonically amplified with increasing the fiber volume fraction, whereas the impact resistance increased up to a critical value of the fiber volume fraction and then declined.

Corrales et al. [16] studied the chemical modification of jute fibers using a fatty acid derivate (oleoyl chloride) to confer hydrophilicity and resistance to biofibers. Vilaseca et al. [17] evaluated the influence of the degree of adhesion at fiber-matrix interface to the mechanical properties of the starch based composites reinforced with jute strands. The alkali treatment was carried out for jute strands and the mechanical properties of the equivalent composite was determined. Akil et al. [18] considered the effects of water absorption on mechanical properties of jute fiber reinforced with unsaturated polyester. Das et al. [19] reported that the tensile strength of the biocomposite films (with 5, 10 and $15 \mathrm{wt} \%$ filler) increased by 51\%, $130 \%$ and $197 \%$, respectively in comparison to the unreinforced one, because of effective stress transfer 
at the interface between the constituents. Thitithanasarn et al. [20] investigated the reinforcement of commodity thermoplastic with various natural fibers. Hossain et al. [21] studied jute composites made with the vacuum assisted resin infiltration (VARI) techniques having different jute fiber preform stacking sequences. Hojo et al. [22] studied several kinds of composites with natural fiber mat as reinforcement (jute, kenaf and bamboo) and unsaturated polyester (UP) as matrix.

This article presents the development of fully 'Green' untreated jute fiber composites based on potato starch matrix. These composites are designed to obtain improved mechanical properties by modifying starch matrix (glycerol as plasticizer) with jute fiber. The aim of this investigation is to use a combination of natural fiber and starch, and fabricate bio-composites which would replace the expensive, hazardous or depleting materials.

\section{Experimental Section}

\subsection{Materials}

Starch has been used as the matrix material in the present study. Starch or amylum is a carbohydrate containing large number of glucose units linked by glycosidic bonds. It is the most common carbohydrate in the human diets and is found in great amounts in staple foods as such potatoes, wheat, maize, rice, and cassava. Pure starch is a white, tasteless and odorless powder that is insoluble in cold water or alcohol. Figure 1 shows the whitish appearance of starch. Different properties of starch are illustrated in table 1. Starch consists of two types of molecules; the linear and helical amylose and the branched amylopectin. Depending on the plant, starch generally contains 20-25\% amylose and 75-80\% amylopectin by weight. 


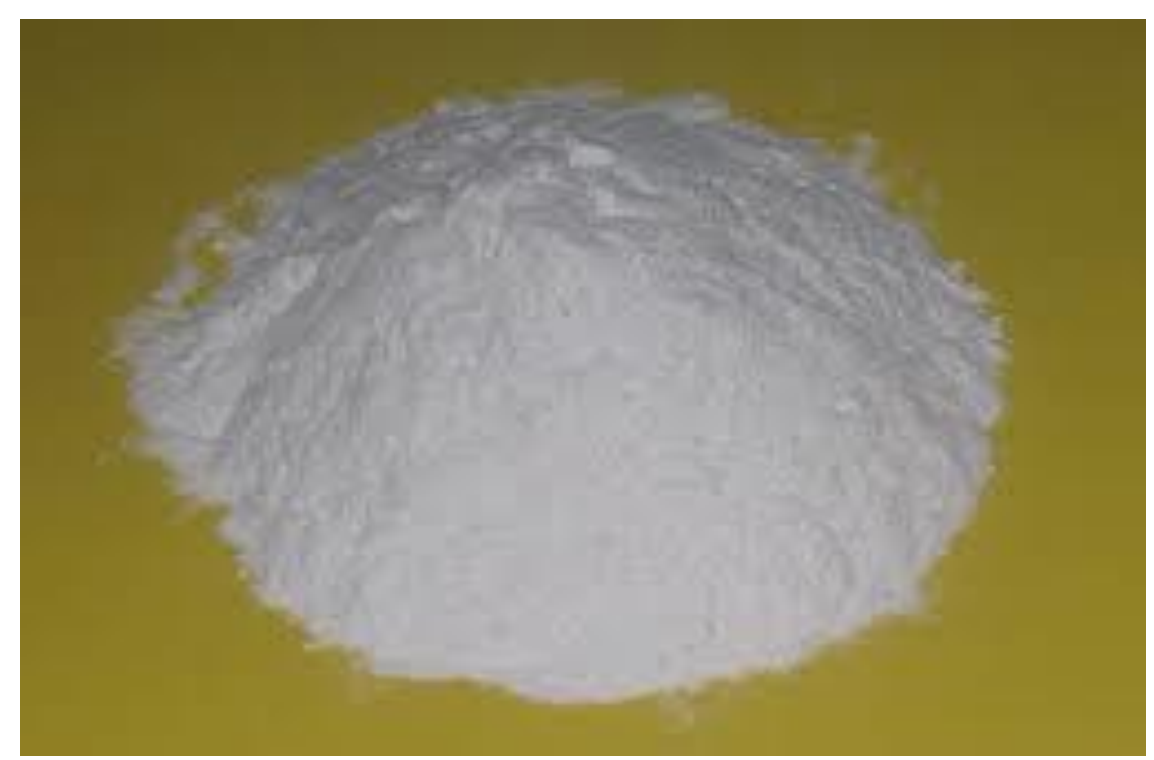

Fig. 1. Starch

Table 1: Properties of starch [23, 24]

\begin{tabular}{|c|c|}
\hline Molecular formula & $\left(\mathrm{C}_{6} \mathrm{H}_{10} \mathrm{O}_{5}\right)_{\mathrm{n}}$ \\
\hline Molar mass & Variable \\
\hline Appearance & White powder \\
\hline Density & $1.5 \mathrm{~g} / \mathrm{cm}^{3}$ \\
\hline Solubility in water & Insoluble \\
\hline Auto ignition temperature & $410{ }^{\circ} \mathrm{C}$ \\
\hline Classification & Carbohydrate \\
\hline
\end{tabular}

Herein, potato starch has been utilized that contains approximately 800 ppm phosphate bound to the starch; this increases the viscosity and gives the solution a slightly anionic character, a low gelatinization temperature and high swelling power. 
Jute fiber has been used as the reinforcing material in this study (Figure 2). The structure of the jute fiber is influenced by the climatic conditions, age and the fermentation process, which also influence their chemical composition (Table 2). The jute fiber holds moderately high specific strength and stiffness. Therefore, it is appropriate as a reinforcement in a polymeric resin matrix. Mechanical properties such as ultimate tensile strength (UTS) and initial modulus are related to the internal structure and chemical composition of fiber. Jute produced from plants of the genus Corchorus, is one of the cheapest natural fibers and is the fiber with the highest production volume in India, Bangladesh and China.

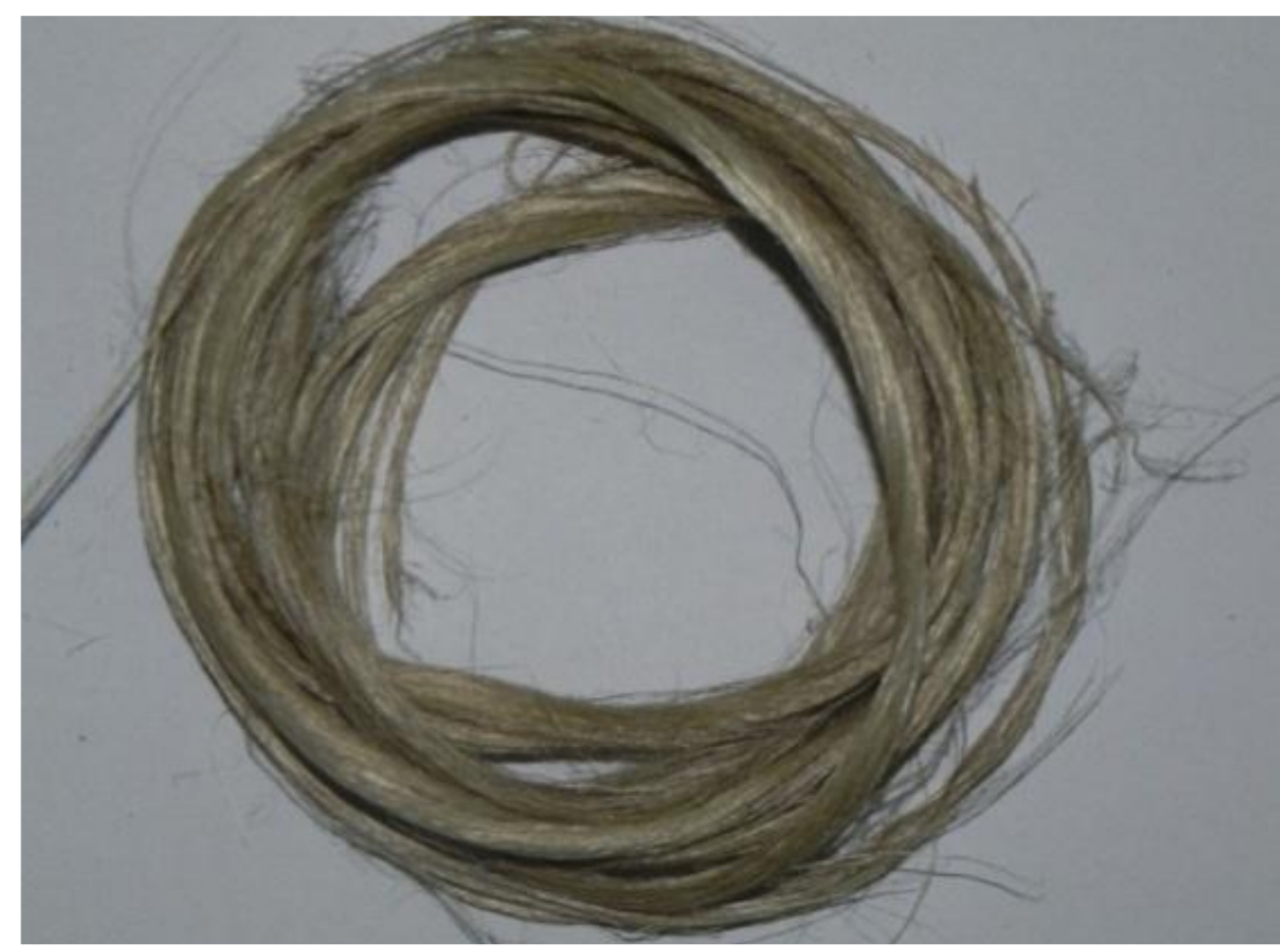

Fig. 2. Raw jute fiber 
Table 2: Chemical composition of jute fiber [25]

\begin{tabular}{|c|c|c|}
\hline \multirow{2}{*}{ Constituents } & \multicolumn{2}{|c|}{ Jute } \\
\cline { 2 - 3 } (in \% of Dry Weight of the Fiber) & C. capsularis & C. olitorius \\
\hline Alphacellulose & $60.0-63.0$ & $58.0-59.0$ \\
\hline Hemicellulose & $21.0-24.0$ & $22.0-25.0$ \\
\hline Lignin & $12.0-13.0$ & $13.0-14.0$ \\
\hline Fats \& Waxes & $0.4-1.0$ & $0.4-0.9$ \\
\hline Pectin & $0.2-1.5$ & $0.2-0.5$ \\
\hline Proteins / Nitrogenous matter, etc. & $0.80-1.9$ & $0.8-1.6$ \\
\hline Ash & $0.7-1.2$ & $0.5-1.2$ \\
\hline
\end{tabular}

Jute fiber is $100 \%$ bio-degradable and recyclable and thus environmental friendly. It is the cheapest natural fiber procured from the bast or skin of the plant's stem. It is the second most important natural fiber after cotton, in terms of usage, global consumption, production, and availability. It has been used in raw materials for packaging, textiles, non-textile, and agricultural sectors. It is also the most environment-friendly fiber starting from the seed to expired fiber, as the expired fibers can be recycled more than once.

Glycerol has been used as a plasticizer in the present study. Its function is to bind the starch molecules and water molecules strongly when heat is applied. Glycerol (glycerine/glycerin) is a simple polyol (sugar alcohol) compound, and is colorless, odourless and viscous liquid. In this study, glycerol is produced as a co-product in the production of long-chain carboxylate salts used as soaps. Properties of glycerol are listed in table 3. 
Table 3: Properties of glycerol [23, 26]

\begin{tabular}{|c|c|}
\hline IUPAC name & Propane-1,2,3-triol \\
\hline Molecular formula & $\mathrm{C}_{3} \mathrm{H}_{8} \mathrm{O}_{8}$ \\
\hline Appearance & Colorless liquid hygroscopic \\
\hline Odor & Odorless \\
\hline Density & $1.261 \mathrm{~g} / \mathrm{cm}^{3}$ \\
\hline Melting point & $17.8^{\circ} \mathrm{C}$ \\
\hline Boiling point & $290^{\circ} \mathrm{C}$ \\
\hline Viscosity & $1.412 \mathrm{~Pa}-\mathrm{s}$ \\
\hline
\end{tabular}

Citric acid (CA) is a weak organic (carboxylic) acid, which exists in greater than trace amounts in a variety of fruits and vegetables and due to its multi-carboxyl structure, it is recognized as a cross-linking agent for starch modification. CA is used in this study because it is recognized as nutritionally harmless as compared to other substances used for starch derivative. Properties of CA are shown in table 4.

Table 4: Properties of citric acid [23, 27]

\begin{tabular}{|c|c|}
\hline IUPAC name & 2-hydroxypropane-1,2,3-tricarboxylic acid \\
\hline Molecular formula & $\mathrm{C}_{6} \mathrm{H}_{8} \mathrm{O}_{7}$ \\
\hline Molar mass & $192.12 \mathrm{~g} / \mathrm{mol}$ \\
\hline Appearance & Crystalline white solid \\
\hline Odor & Odorless \\
\hline density & $1.665 \mathrm{~g} / \mathrm{cm}^{3}$ \\
\hline Melting point & $156^{\circ} \mathrm{C}$ \\
\hline Boiling point & $310^{\circ} \mathrm{C}$ \\
\hline
\end{tabular}


Vinegar (acetic acid $\left(\mathrm{CH}_{3} \mathrm{COOH}\right)$ and water) has been used in the present study as an antibacterial and anti-fungal substance. It is produced by the fermentation of ethanol by acetic acid bacteria and is mainly used as a household cleanser.

Epoxy resin (Araldite CY-230) has wide range of industrial applications because of its high strength and mechanical adhesiveness characteristic. Physical and chemical properties of Epoxy resin are shown in table 5.

Table 5: Physical and chemical properties of Epoxy resin (CY-230)

\begin{tabular}{|c|c|c|}
\hline S.No. & & Epoxy Resin (Araldite CY-230) \\
\hline 1. & $\begin{array}{l}\text { Physical } \\
\text { Properties }\end{array}$ & $\begin{array}{l}\text { Yellow-brown coloured, odourless, tasteless, nontoxic, low } \\
\text { shrinkage, and density }=1150 \mathrm{~kg} / \mathrm{m}^{3}\end{array}$ \\
\hline 2. & Chemical & $\begin{array}{l}\text { Product of reaction between bisphenol A and epichlorohydrin with } \\
\text { some amount of toluene }\end{array}$ \\
\hline 3. & $\begin{array}{l}\text { Chemical } \\
\text { composition }\end{array}$ & 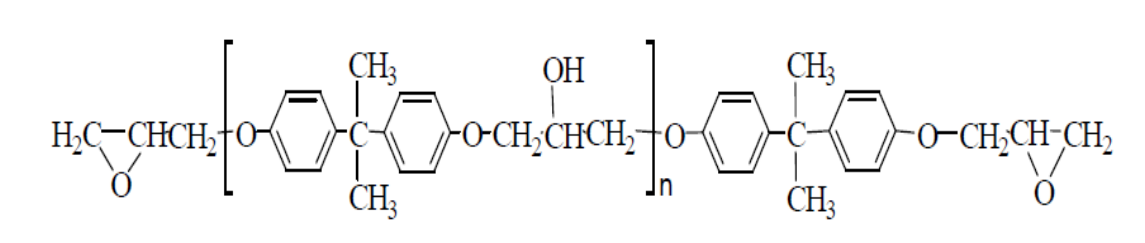 \\
\hline
\end{tabular}

In the current inspection, epoxy resin (CY-230) [28], diglycidyl ether of bisphenol-A (DGEBA, EPON 828), purchased from M/s CIBATUL Limited [29], India has been used as the matrix material. Hardener (HY-951) is a yellowish-green coloured liquid and was too purchased from M/s CIBATUL Limited, India; and acts as a curing agent for the experimentation. In the present investigation, a mixture of 100 parts by weight of DGEBA and 9 parts by weight of hardener (HY-951) has been used in all the materials developed. The wt $\%$ of hardener used in the existing analysis is as per the reference of Singh and Gope [30]. 


\subsection{Methodology}

The methodology used in this study for preparing starch-jute composite is as per the authors previous work on sisal fiber [23]; except the fiber used here is the jute fiber.

\section{(i) Alkaline Treatment:}

Firstly, the jute fibers were soaked in an alkaline solution of $2 \%$ sodium hydroxide $(\mathrm{NaOH})$, at a temperature of $22 \pm 2{ }^{\circ} \mathrm{C}$ for 24 hours. The authors have treated the jute fiber surface with $\mathrm{NaOH}$ (alkaline treatment) to boost the interfacial adhesion between biological fibers and polymers. Also, the alkaline treatment removes a definite quantity of oil, wax and impurity that coats the exterior surface of fiber. Then it is washed with distilled water and left for drying before being put in an oven for 15 hours at $70^{\circ} \mathrm{C}$. Finally, the jute fibers were sliced into $2-3$ mm length size.

(ii) Solvent-Cast Film Preparation Method:

Starch (30 g) and glycerol ( 9.9 g) were thoroughly mixed together; followed by adding 1000 $\mathrm{mL}$ distilled water to this mixture. As an anti-bacterial substance $5 \mathrm{~mL}$ of vinegar was used. This mixture was boiled while stirring for 1 hour, which is done on magnetic stirrer and allowed to cool to $75{ }^{\circ} \mathrm{C}$. Followed by casting on a nonstick tray and placed in a $65{ }^{\circ} \mathrm{C}$ oven to dry. Finally, it was mixed with jute fibers and put in the mould. Starch solutions at the time of stirring and after stirring are shown in Figures 3 and 4, respectively.

(iii) Hot-Pressed Film Preparation Method:

Cast films were crushed and then hydrated to $25 \mathrm{wt} \%$ moisture, and then allowed to equilibrate for 24 hours. Films were made by hot-pressing the hydrated material in a steel plate mould (dimensions of $90 \times 60 \times 1 \mathrm{~mm}^{3}$ ) at different temperature and pressure in a compression moulding machine. 
(iv) Epoxy Coating:

The jute fiber composite samples are dried at $80^{\circ} \mathrm{C}$ for $1 \mathrm{hr}$, prior to immersion in epoxy resin bath (DGEBA). After 2 minutes of immersion, the samples are hung-up and permitted to cure at room temperature for 2 days. Finally, the epoxy resin (CY-230) gets deposited on the jute fiber composite sample [31].

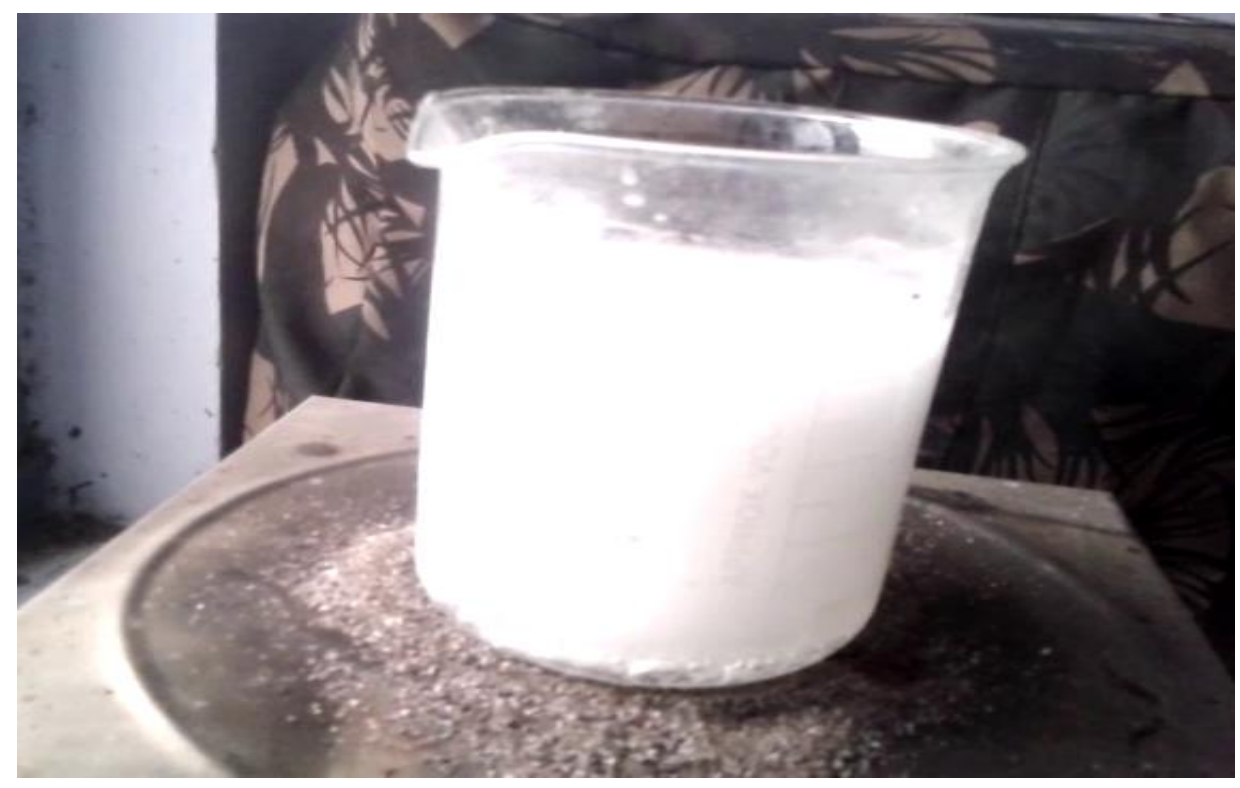

Fig. 3. Starch solution at the time of stirring

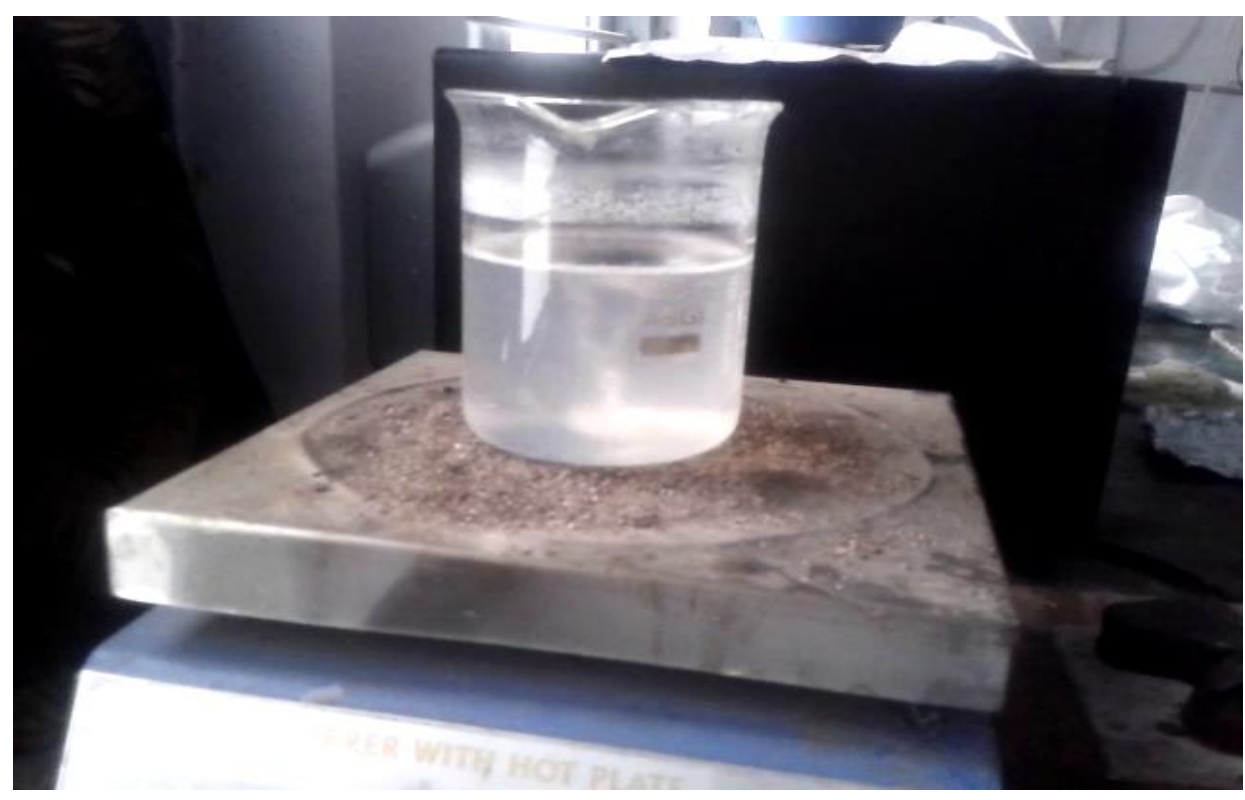

Fig. 4. Starch solution after stirring 


\subsection{Characterization}

In this scrutiny, all the tensile tests are directed as per ASTM D638 and ASTM D3039 test procedures $[32,33]$. According to these standards, dimensions of each test specimen were having width $25 \mathrm{~mm}$, length $250 \mathrm{~mm}$ and thickness $2.5 \mathrm{~mm}$ (Figure 5). The tests are conducted on a $100 \mathrm{kN}$ servo-hydraulic tensile testing machine (model 2008, ADMET, India) with a crosshead speed of $0.5 \mathrm{~mm} / \mathrm{min}$ (temperature $-30^{\circ} \mathrm{C}$ and relative humidity $(\mathrm{RH})-50 \%$ ).

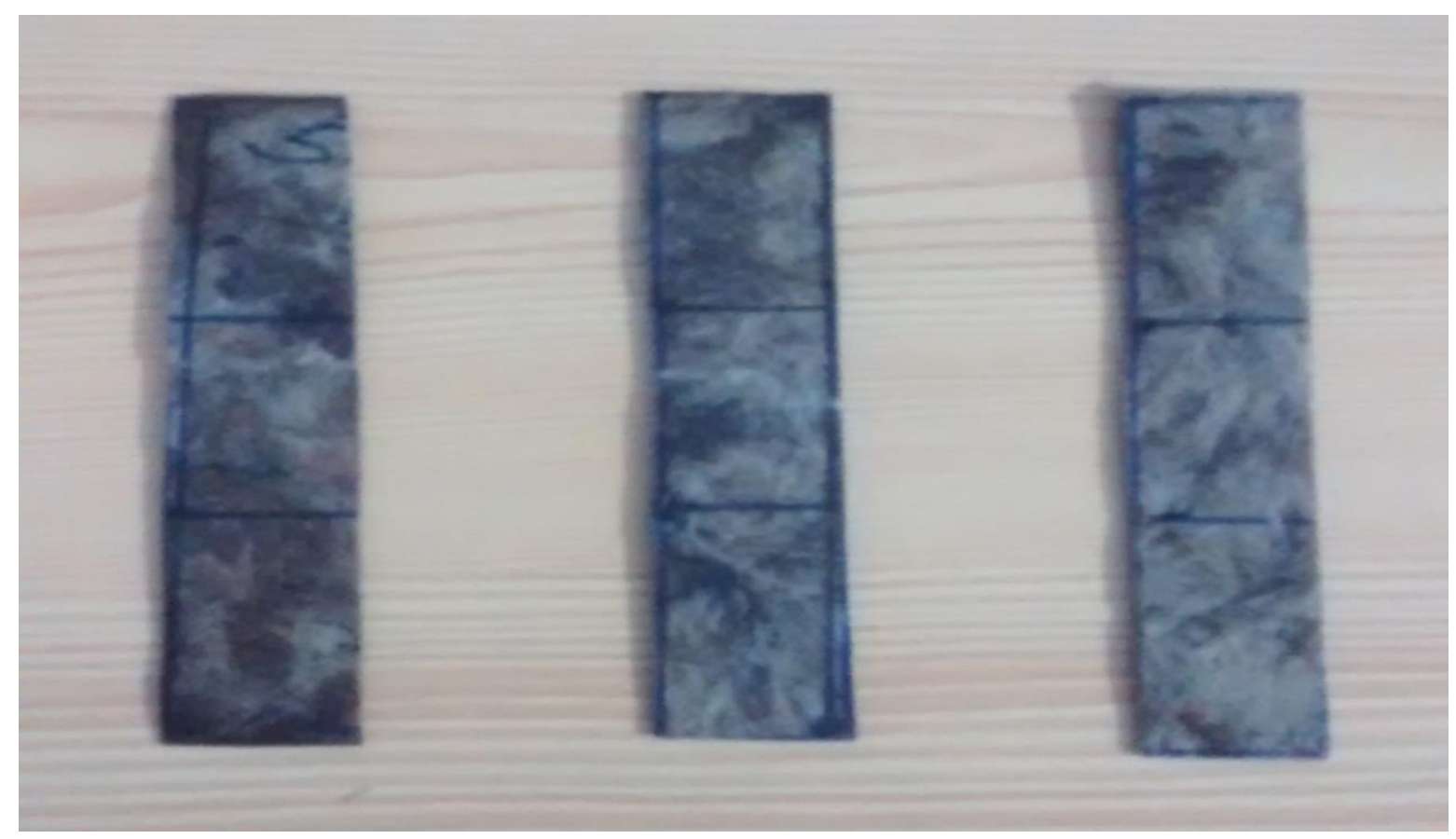

Fig. 5. Tensile test specimens

It is important to study the behaviour of composites when they are exposed to environmental conditions such as temperature and humidity. The natural particle reinforced composites are light weight, reasonably strong, free from natural hazards and degradable with some disadvantages like poor moisture resistance and low strength compared to synthetic fibers. Tests were conducted under water soaking conditions. Specimens were immersed in water having a $\mathrm{pH}$ of 7.1. Specimens were first dried in oven and then submerged in water at room temperature. To determine water absorption electronic weighing machine (least count 0.001 
gram). Before each reading the surface of the specimen was wiped by a tissue paper. Water absorption (WA) is calculated by the equation 1 [34]:

$$
\mathrm{WA}(\%)=\frac{\left(\mathrm{W}_{2}-\mathrm{W}_{1}\right)}{\mathrm{W}_{1}} \times 100
$$

where, $\quad \mathrm{W}_{1}=$ initial specimen weight, in grams

$\mathrm{W}_{2}=$ specimen weight after ' $\mathrm{N}$ ' hours of water soaking, in grams

In this work, the scanning electron microscopy (SEM) study has been done to see the dispersion of jute fiber in biodegradable resin. The images are obtained through microscopic investigation with LEO435V6. To obtain SEM images square samples are cut from the cast material and are gold coated to avoid the artifacts associated with sample charging and then placed inside a chamber in which an electron beam with an accelerated voltage of $10 \mathrm{kV}$ falls on the material.

Thermal analysis is the branch of science where the properties of materials are studied as they change with temperature [35]. In thermal analysis section, Thermo Gravimetric Analysis (TGA) and Differential Thermal Analysis (DTA) are done. The thermal analysis was carried out using TG analyzer (EXSTAR TG/DTA 6300) at IIT, Roorkee by heating the samples in still air $(200 \mathrm{~mL} / \mathrm{min})$ at $10^{\circ} \mathrm{C} / \mathrm{min}$ from $0{ }^{\circ} \mathrm{C}$ to $250{ }^{\circ} \mathrm{C}$. Thermo gravimetry (TG) is the branch of thermal analysis which examines the mass change of a sample as a function of temperature in the scanning mode or as a function of time in the isothermal mode. TG is most useful for dehydration, decomposition, desorption and oxidation processes. Another widely used thermal method of analysis is Differential Thermal Analysis (DTA). In DTA, the temperature of a sample is compared with that of an inert reference material during a programmed change of temperature [36]. 


\section{Results and discussion}

Tensile test, water absorption test, SEM, and TGA/DTA were performed on starch-jute fiber based composite. Results for the above performed tests are discussed in subsequent section.

\subsection{Tensile Test}

The tensile properties were carried out on $100 \mathrm{kN}$ ADMET made servo-controlled Universal Testing Machine (UTM) at a fixed strain rate of $0.5 \mathrm{~mm} / \mathrm{min}$ under displacement control mode [37]. Tensile tests were conducted for various compositions of jute fiber. Samples were prepared according to the ASTM D638 standard. Stress-strain curves obtained for different wt $\%$ of jute fiber prepared by compression at different temperatures and pressures have been shown in this section.

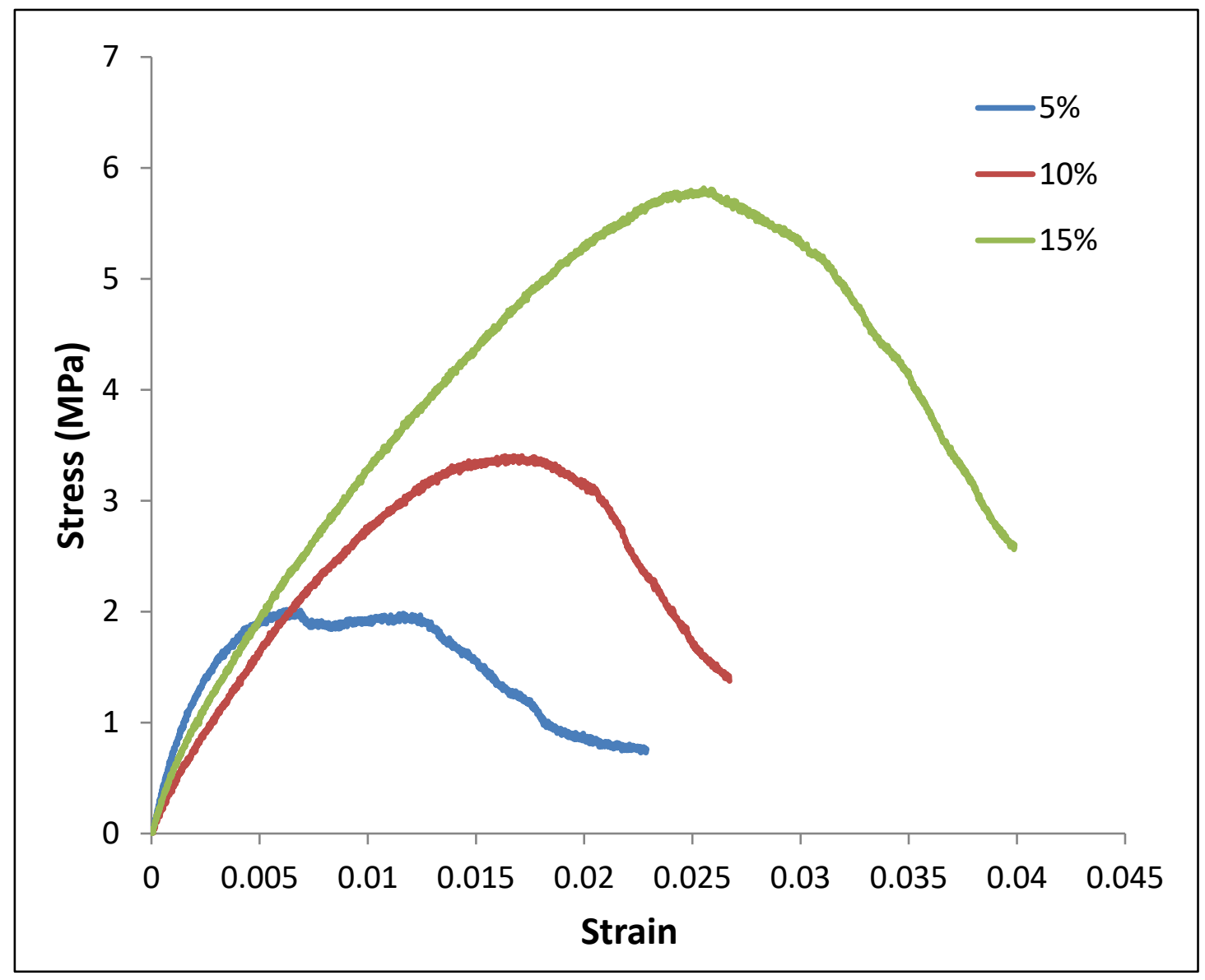

Fig. 6. Stress-Strain curve for samples prepared at $60^{\circ} \mathrm{C}$ temperature and 70 bar pressure 
Figure 6 shows the stress-strain curve for samples prepared by compression at $60^{\circ} \mathrm{C}$ temperature and 70 bar pressure. Three samples containing $5 \mathrm{wt} \%, 10 \mathrm{wt} \%$ and $15 \mathrm{wt} \%$ of jute fiber are plotted. The tensile strength rises with increasing fiber content and sample containing $15 \mathrm{wt} \%$ of jute fiber shows the maximum strength. UTS obtained for sample containing $15 \mathrm{wt} \%$ of jute fiber is $5.768 \mathrm{MPa}$, for $10 \mathrm{wt} \%$ of jute fiber is $3.375 \mathrm{MPa}$ and for $5 \mathrm{wt} \%$ of jute fiber is 1.93 $\mathrm{MPa}$; as compared to $1.78 \mathrm{MPa}$ for the neat starch matrix.

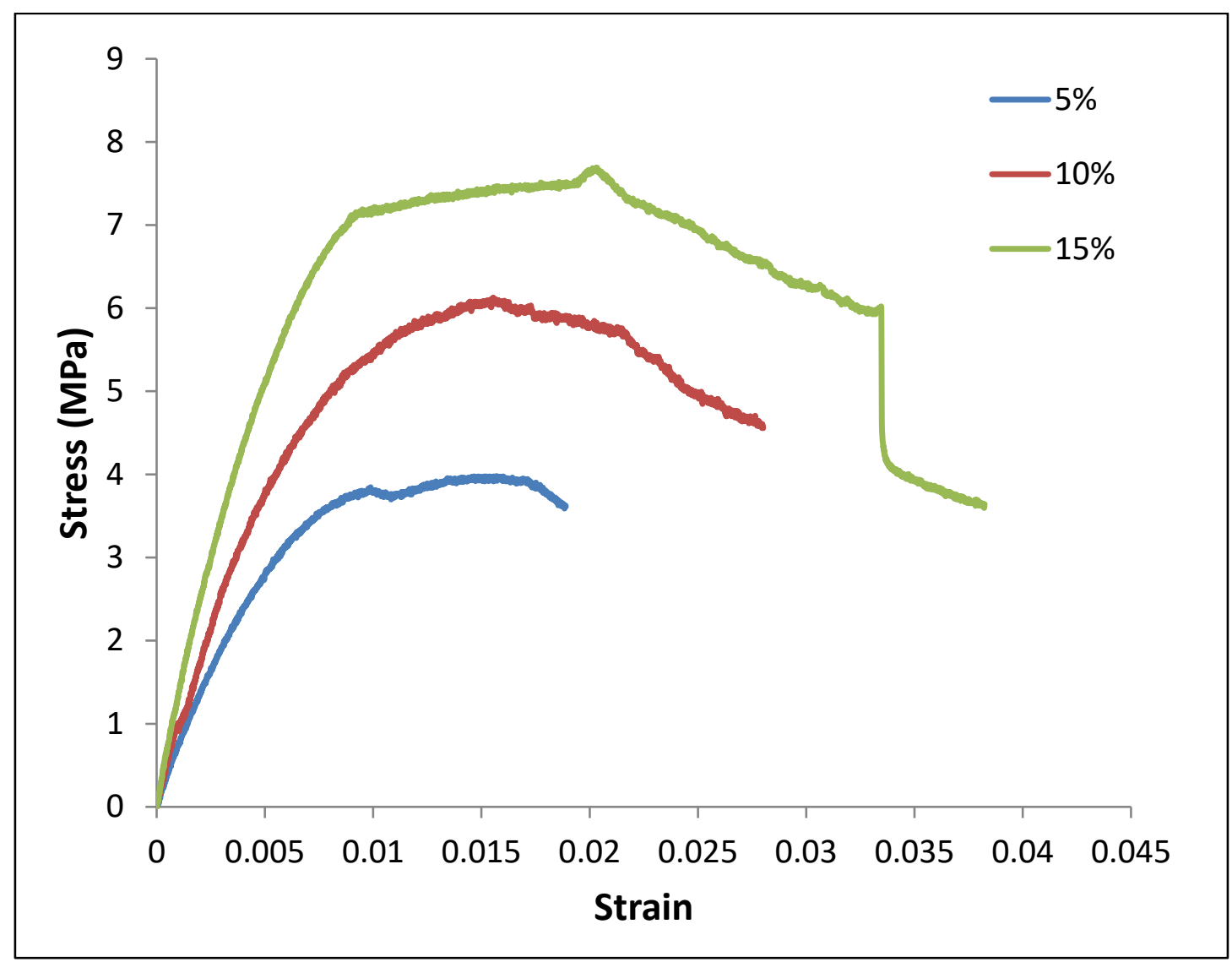

Fig. 7. Stress-Strain Curve for samples preparedat $70^{\circ} \mathrm{C}$ temperature and 70 bar pressure

Figure 7 shows the stress-strain curve for samples prepared by compression at $70^{\circ} \mathrm{C}$ temperature and 70 bar pressure. Three samples containing $5 \mathrm{wt} \%, 10 \mathrm{wt} \%$ and $15 \mathrm{wt} \%$ of jute fiber are plotted. The tensile strength is found to be maximum for sample containing $15 \%$ fiber by weight. UTS for sample containing $15 \mathrm{wt} \%$ of fiber is $7.547 \mathrm{MPa}$, for $10 \mathrm{wt} \%$ of fiber is $6.063 \mathrm{MPa}$ and for $5 \mathrm{wt} \%$ of fiber is $3.96 \mathrm{MPa}$. 


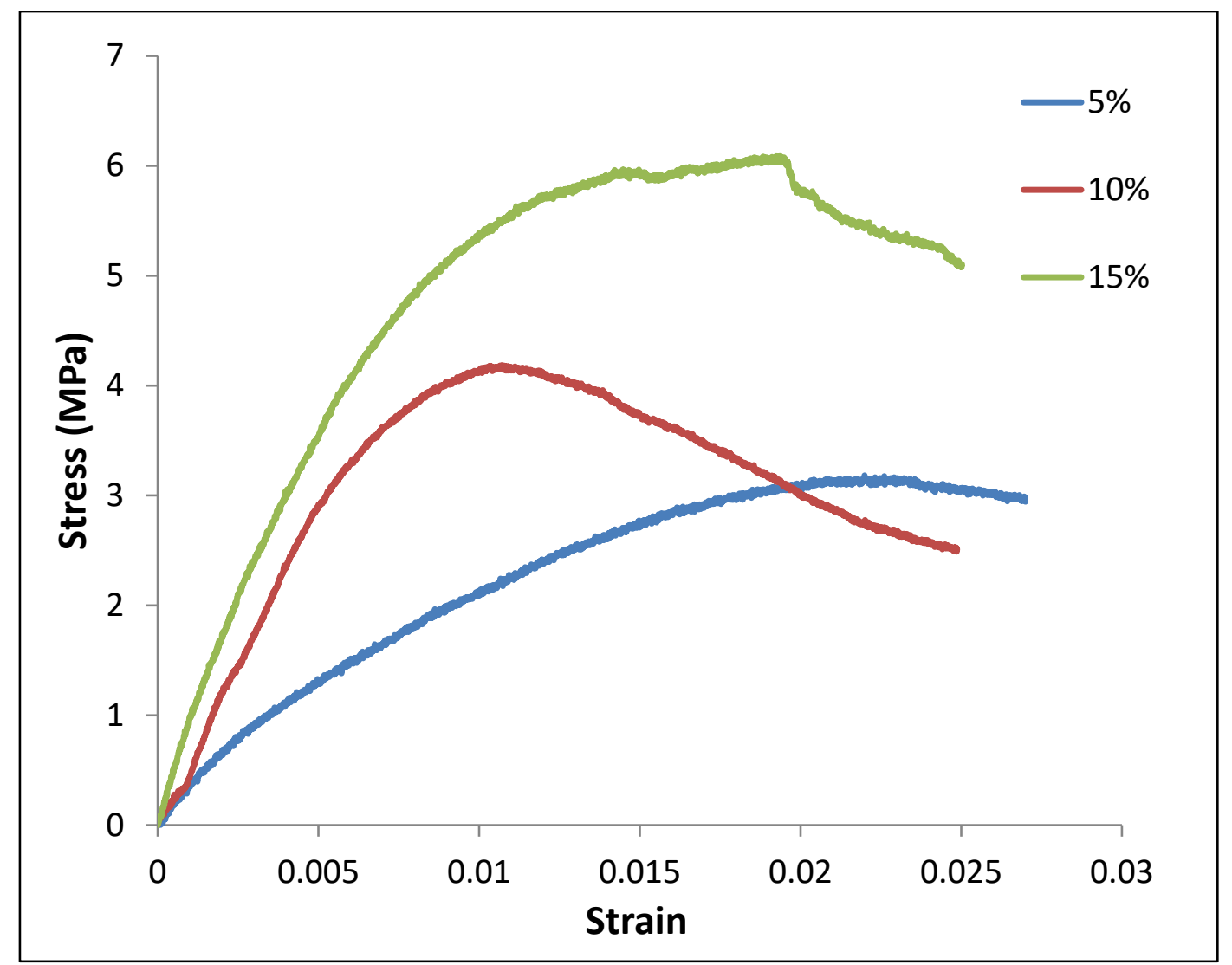

Fig. 8. Stress-Strain curve for samples prepared at $80^{\circ} \mathrm{C}$ temperature and 70 bar pressure

Figure 8 shows the stress-strain curve for samples prepared by compression at $70^{\circ} \mathrm{C}$ temperature and 70 bar pressure. Three samples containing $5 \mathrm{wt} \%, 10 \mathrm{wt} \%$ and $15 \mathrm{wt} \%$ of jute fiber are plotted. UTS obtained for sample containing $15 \mathrm{wt} \%$ of fiber is $6.592 \mathrm{MPa}$, for $10 \mathrm{wt} \%$ of fiber is $4.147 \mathrm{MPa}$ and for $5 \mathrm{wt} \%$ of fiber is $3.147 \mathrm{MPa}$. 


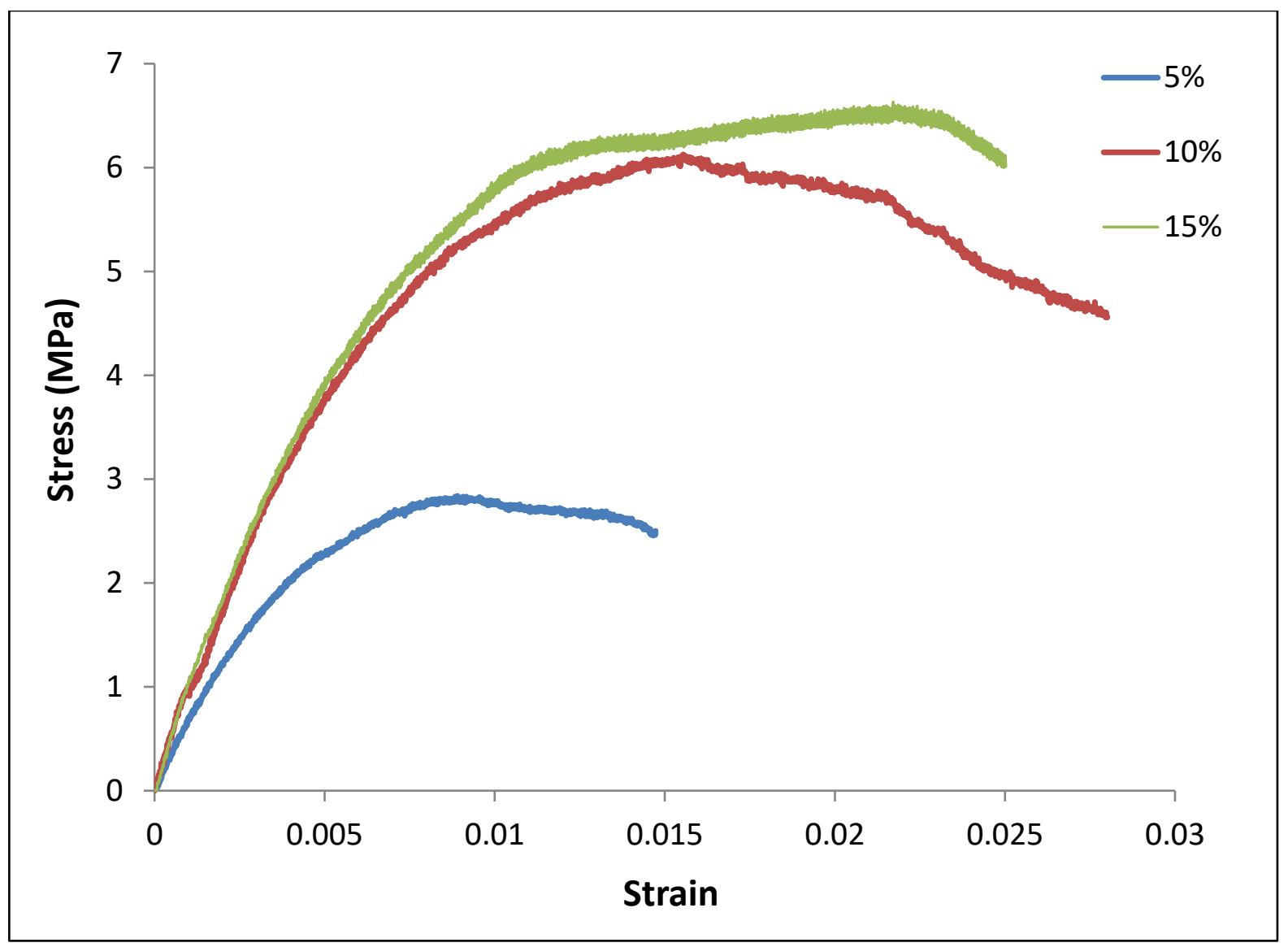

Fig. 9. Stress-Strain curve for samples prepared at $90^{\circ} \mathrm{C}$ temperature and 70 bar pressure

Figure 9 shows the stress-strain curve for samples prepared by compression at $90^{\circ} \mathrm{C}$ temperature and 70 bar pressure. Three samples containing $5 \mathrm{wt} \%, 10 \mathrm{wt} \%$ and $15 \mathrm{wt} \%$ of jute fiber are plotted. UTS obtained for samples containing $15 \mathrm{wt} \%$ of fiber is $6.58 \mathrm{MPa}$, for $10 \mathrm{wt} \%$ of fiber is $6.05 \mathrm{MPa}$ and for $5 \mathrm{wt} \%$ of fiber is $2.803 \mathrm{MPa}$. From the above performed tests, it can be concluded that the highest UTS was shown by the samples prepared at $70^{\circ} \mathrm{C}$ temperature and 70 bar pressure with UTS $=7.547 \mathrm{MPa}$ (for sample containing $15 \%$ jute fiber by weight). Therefore, the samples prepared at $70^{\circ} \mathrm{C}$ temperature and 70 bar pressure are considered for further investigation.

As already stated, these natural composites lack the capability to resist the moisture environment. That's why the authors have considered an epoxy resin coating over it. Samples 
containing $5 \mathrm{wt} \%, 10 \mathrm{wt} \%$ and $15 \mathrm{wt} \%$ jute fiber and prepared by compression at $70^{\circ} \mathrm{C}$ temperature and 70 bar pressure are coated with a thin layer of epoxy. Tensile test is then performed on the samples containing a thin layer of epoxy. Figure 10 shows the graph plotted between stress and strain. UTS obtained for sample containing $15 \mathrm{wt} \%$ of fiber is $10.46 \mathrm{MPa}$, for $10 \mathrm{wt} \%$ of fiber is $10.28 \mathrm{MPa}$ and for $5 \mathrm{wt} \%$ of fiber is $4.68 \mathrm{MPa}$.

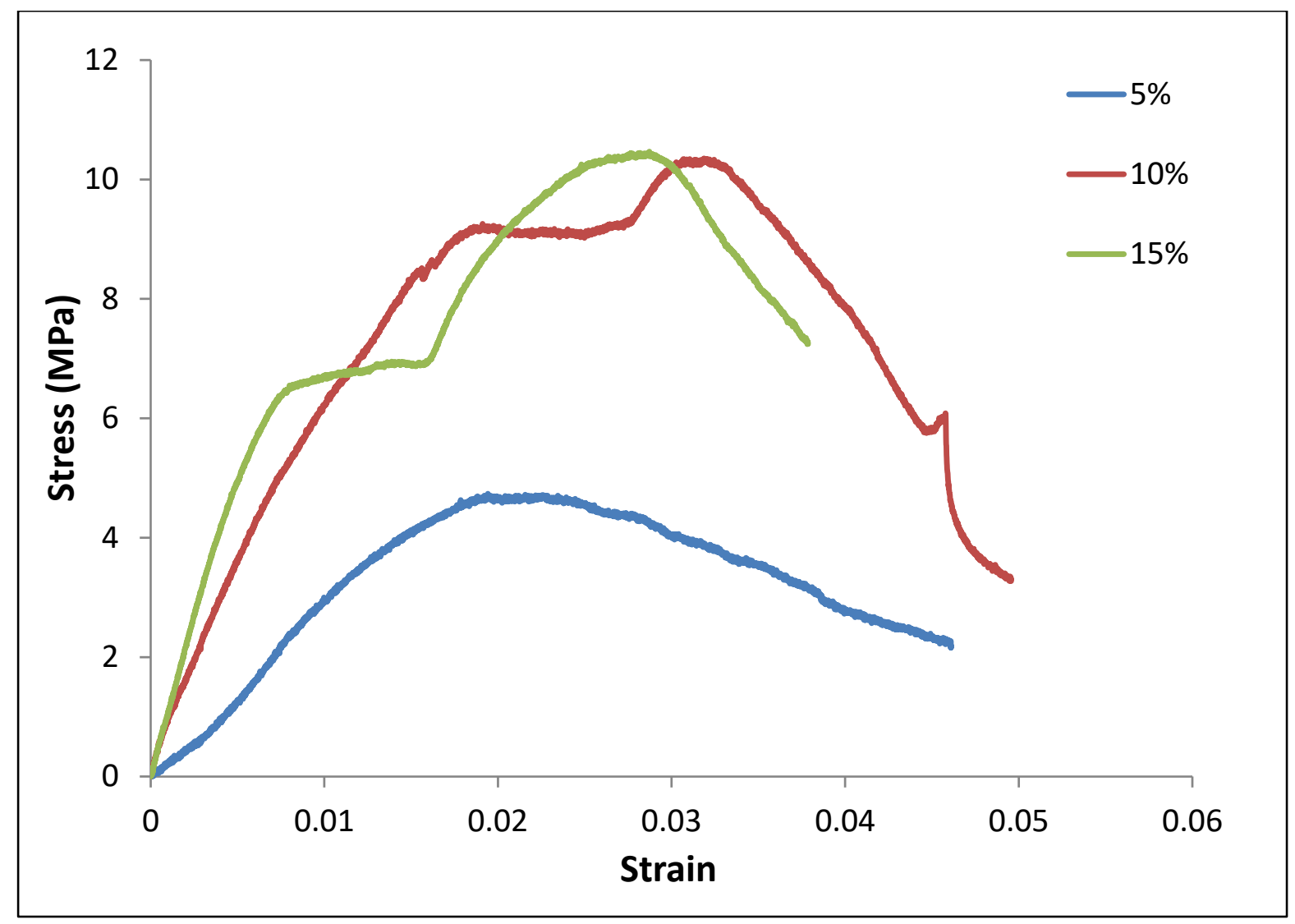

Fig. 10. Stress-Strain curve for samples prepared at $70^{\circ} \mathrm{C}$ temperature and $70 \mathrm{bar}$ pressure with epoxy coating

Figure 11 shows a comparison between UTS and wt $\%$ of fiber composites. Three samples containing $5 \%, 10 \%$ and $15 \%$ jute fiber by weight with epoxy coating and without coating of epoxy (samples prepared at $70^{\circ} \mathrm{C}$ temperature and 70 bar pressure) are plotted. The UTS for samples containing $15 \mathrm{wt} \%$ of fiber is $10.46 \mathrm{MPa}$, for $10 \mathrm{wt} \%$ of fiber is $10.28 \mathrm{MPa}$ and for $5 \mathrm{wt} \%$ of fiber is $4.68 \mathrm{MPa}$ with epoxy coating and UTS for samples containing $15 \mathrm{wt} \%$ of fiber 
is $7.547 \mathrm{MPa}$, for $10 \mathrm{wt} \%$ of fiber is $6.063 \mathrm{MPa}$ and for $5 \mathrm{wt} \%$ of fiber is $3.96 \mathrm{MPa}$ without epoxy coating. It can be clearly seen from the above graph that the UTS for samples containing epoxy coating is higher than the samples without epoxy coating.

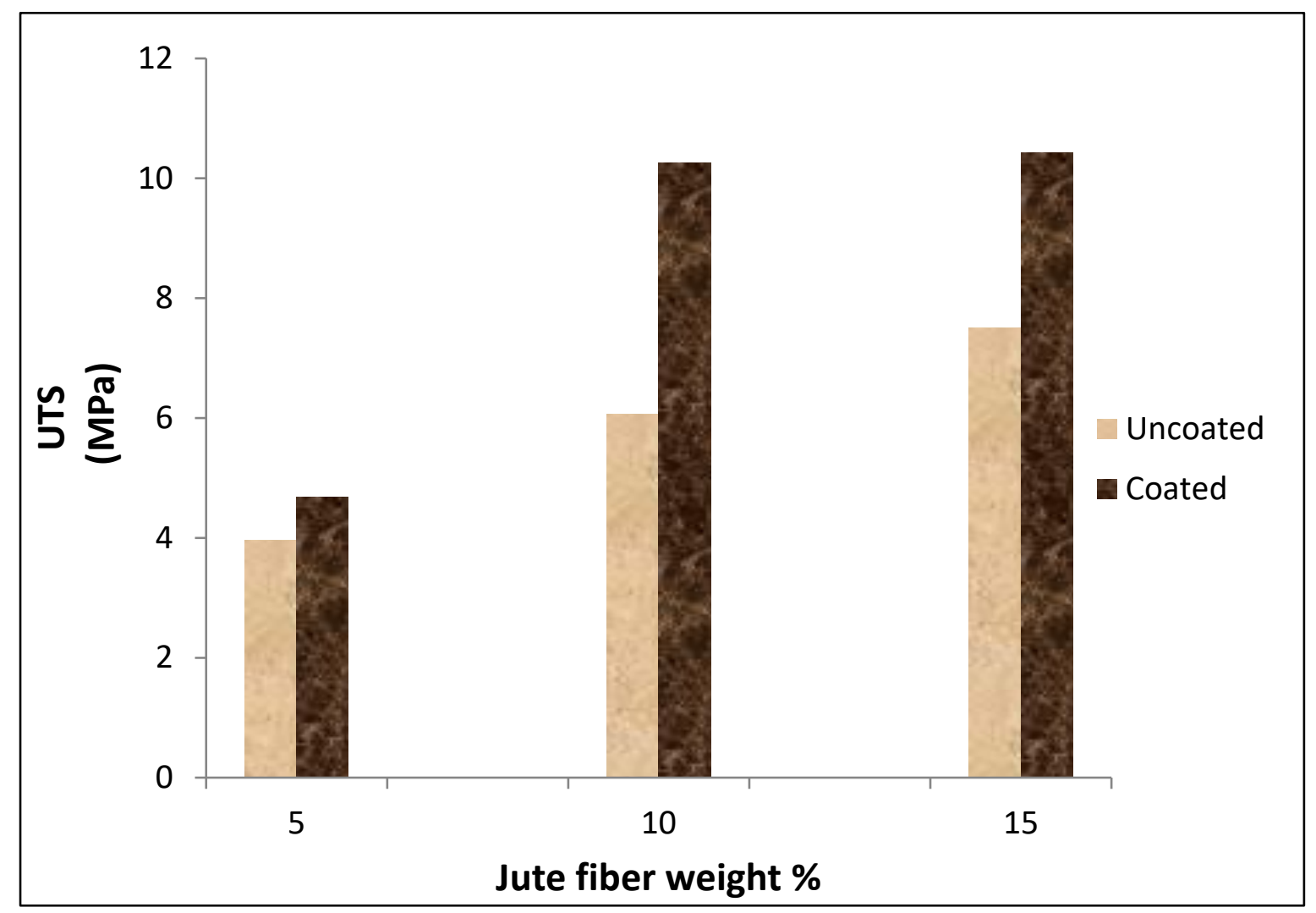

Fig. 11. UTS for coated and uncoated samples

As can be seen from the Figure 11, the UTS for samples without epoxy coating $(5 \%, 10 \%$ and $15 \%$ jute fiber by weight) rises gradually. For samples with epoxy coating the UTS is higher than the samples without epoxy coating. However, for samples $10 \%$ fiber by weight and $15 \%$ fiber by weight the difference in the UTS is not much. The rise in the UTS of samples coated with epoxy resin is due to the absorption of epoxy and enhanced cross-linking that occurs between the epoxy and starch molecules. The absorption of epoxy resin depends upon two factors: (i) the number of voids present in the matrix, and (ii) the absorption of epoxy resin by the fiber. At $5 \mathrm{wt} \%$ of fiber the voids in the matrix of composite are low and also the fiber content is low, hence the increase in the UTS is not much. At $10 \mathrm{wt} \%$ of fiber, the number of 
voids in the matrix increase and also the fiber content rises; therefore, the sample absorbs more resin and hence the strength improves significantly. At $15 \mathrm{wt} \%$ of fiber, amount of fiber in the matrix is very high due to which the space available for absorption of epoxy is not enough. Hence, the strength of the sample rises; but, the increase is not as high as it was for sample containing $10 \mathrm{wt} \%$ of fiber. Table 6 shows the comparison of UTS for samples without epoxy coating and with epoxy coating.

Table 6: Comparison of UTS for uncoated and coated samples

\begin{tabular}{|c|c|c|}
\hline wt \% of jute fiber & UTS Uncoated (MPa) & UTS Coated (MPa) \\
\hline 5 & 3.96 & 4.68 \\
\hline 10 & 6.063 & 10.28 \\
\hline 15 & 7.547 & 10.46 \\
\hline
\end{tabular}

\subsection{Water Absorption Test}

The water absorption (WA) test provides information about the adhesion between the fibers and matrix in the interface region [38]. WA test was done by dipping all the samples in water and then weighing them in time intervals of 10 minutes. Figure 12 shows the WA\% for samples without epoxy coating. As expected the prepared green composite has highly hydrophilic character which is confirmed by the WA test. It can be observed from the figure that in the beginning WA for samples $(5 \mathrm{wt} \%, 10 \mathrm{wt} \%$ and $15 \mathrm{wt} \%$ of jute fiber) without coating is very high. The rate of absorption of the water decreases with time of immersion of the sample in water. WA increases with increasing the fiber content as jute is highly hydrophilic; hence, the increase of WA with increasing fiber content is justified. 


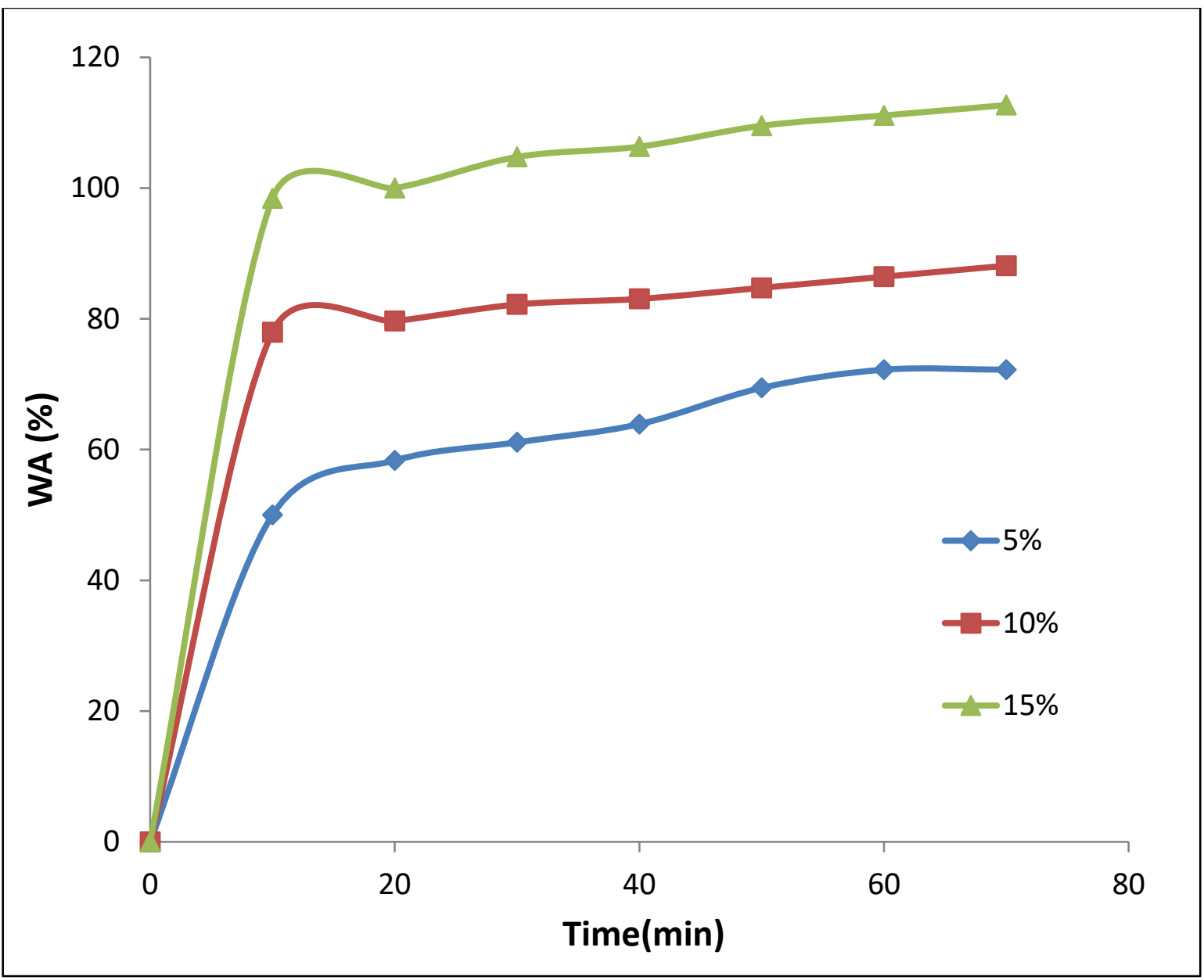

Fig. 12. WA for samples without epoxy coating

Figure 13 shows the WA\% for samples with epoxy coating. As can be observed from the graph the rate of WA has slowed down for different wt $\%$. The amount of water absorption as well as the high rate of absorption has been controlled to a large extent. Figure 14 shows the WA (\%) for all samples (coated and uncoated). 


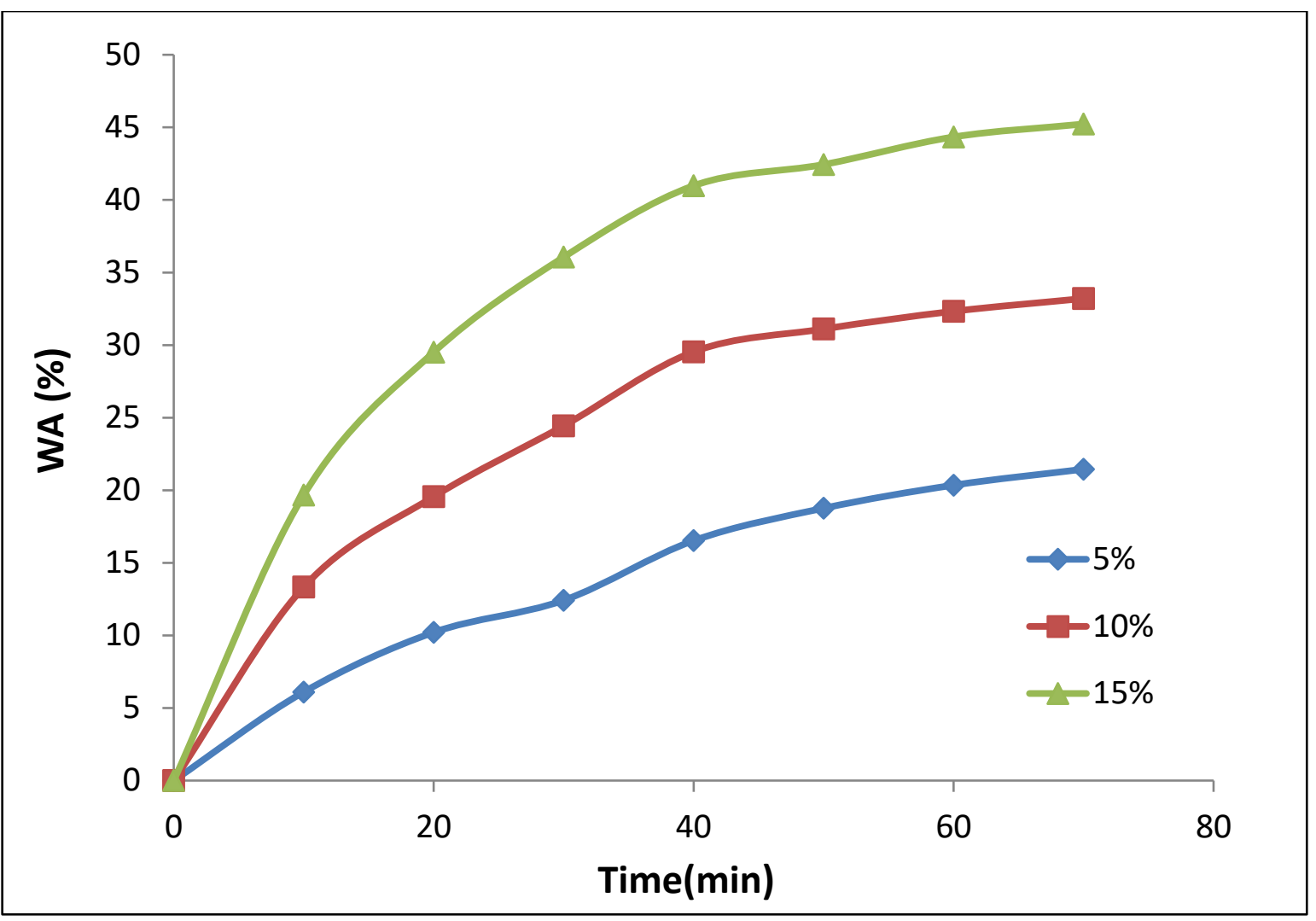

Fig. 13. WA for samples with epoxy coating

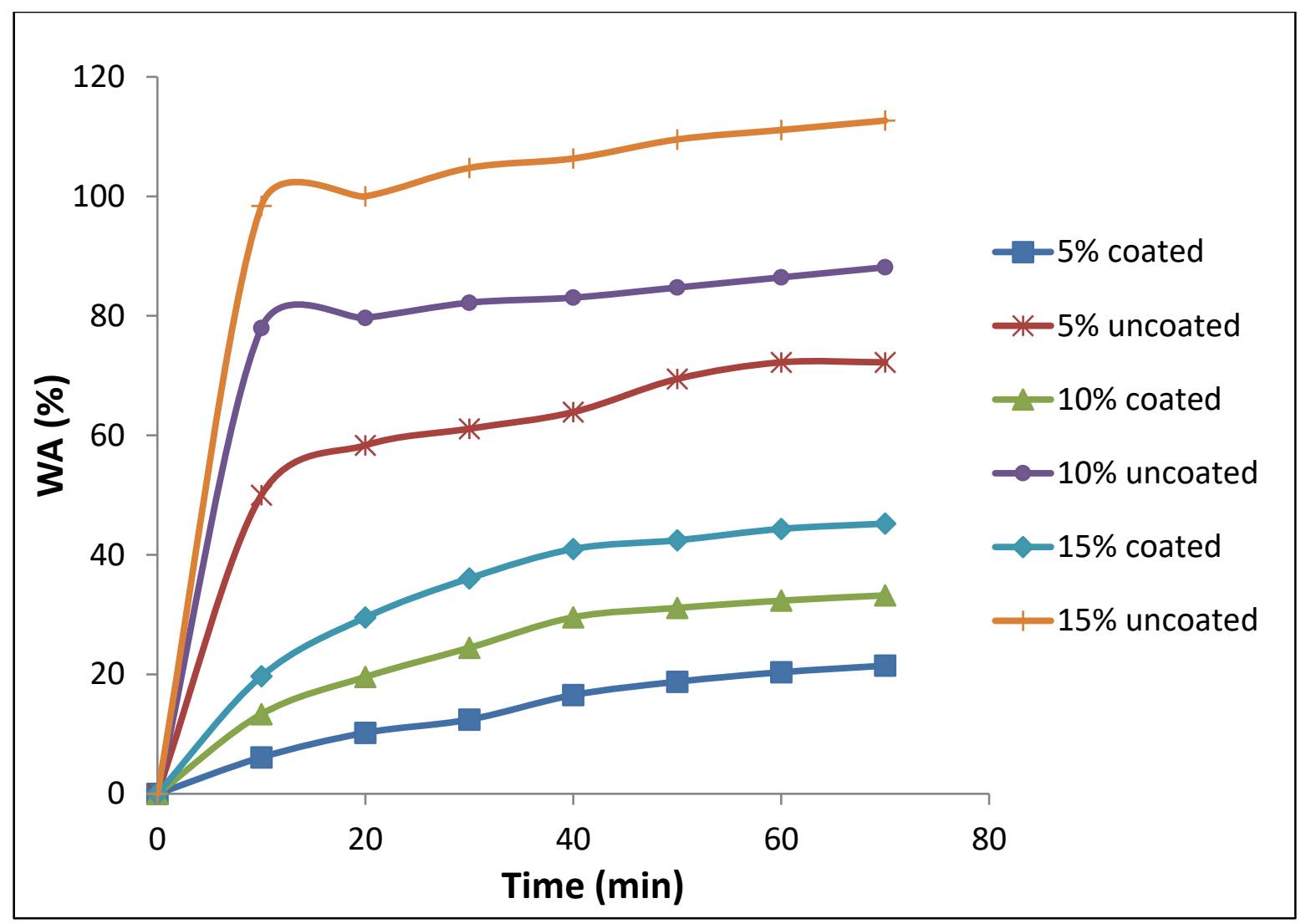

Fig. 14. WA of all the samples (coated and uncoated) 


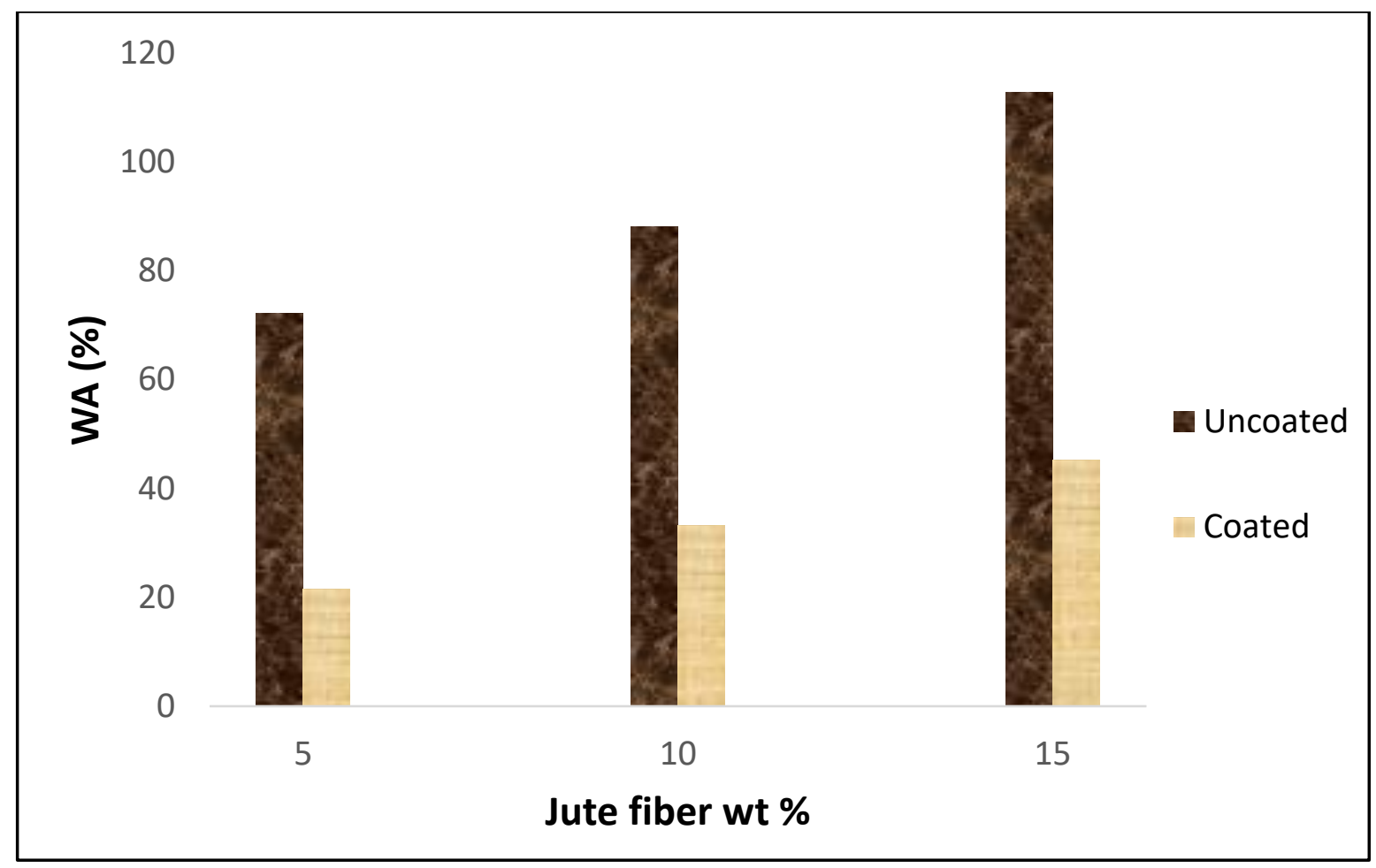

Fig. 15. Maximum WA for uncoated and coated samples

Figure 15 shows comparison between the water absorbed by different wt $\%$ of jute fiber for samples without and with epoxy coating. As can be concluded from the WA test, a thin coating of epoxy reduces the water absorption by a large amount. Water absorbed by sample without epoxy coating is very high, for $5 \mathrm{wt} \%$ of fiber is $72.22 \%$, for $10 \mathrm{wt} \%$ of fiber is $88.13 \%$ and for $15 \mathrm{wt} \%$ of fiber is $112.69 \%$. Water absorption for samples prepared with an epoxy coat is low as compared to the samples prepared without epoxy coat. Water absorption for coated samples containing $5 \%$ fiber by weight is $21.45 \%$, for $10 \%$ fiber by weight is $33.21 \%$ and for $15 \%$ fiber by weight is $45.23 \%$. Reduction in water absorption for $15 \mathrm{wt} \%$ sample is $149 \%$, for $10 \mathrm{wt} \%$ sample is $165.37 \%$ and for sample containing $5 \mathrm{wt} \%$ is $236.68 \%$.

\subsection{Scanning Electron Microscopy analysis}

The cross-sectional views of the fabricated green composite material consisting of starch, different wt\% of jute fiber, are presented in Figures 16-23. The SEM images are taken to 
observe the interfacial properties, internal cracks and internal structure of the fractured surfaces of composite materials. Figure 16-23 show the SEM photographs of surfaces of different composite materials investigated in the present work fractured under the tensile loading. Figures 16, 17 and 18 shows the SEM of $15 \mathrm{wt} \%$ jute fiber composite material with coating at a magnification of 500X, 100X and 50X, respectively. Figure 19 shows the SEM for 10wt $\%$ jute fiber composite material with coating at 100X magnification. Figure 20 shows the SEM for $5 \mathrm{wt} \%$ jute fiber composite material with coating at 50X magnification. Figure 21 shows the SEM for $15 \mathrm{wt} \%$ jute fiber composite material without coating at 500X magnification. Figure 22 shows the SEM for $10 \mathrm{wt} \%$ jute fiber composite material without coating at $100 \mathrm{X}$ magnification. Figure 23 shows the SEM for $5 \mathrm{wt} \%$ jute fiber composite material without coating at $100 \mathrm{X}$ magnification.

Figures 16, 17 and 18 show the fractured surface of 15 wt\% fiber with coating of epoxy at a magnification of 500X, $100 \mathrm{X}$ and $50 \mathrm{X}$, respectively. As it can be seen from these figures that due to higher wt $\%$ of fiber in the matrix, more fibers can be seen on the fractured surface. The higher wt $\%$ of fiber has increased the tensile strength of composite as compared to the strength of uncoated material. In Figure 18, the tangling of the fibers in matrix due to higher wt $\%$ is clearly visible. Figure 19 shows the fractured surface of $10 \mathrm{wt} \%$ of fiber coated with epoxy at a magnification of $100 \mathrm{X}$. Due to low wt $\%(10 \mathrm{wt} \%)$ of fiber, it can be seen that the tangling of fibers is low as compared to sample containing higher $(15 \mathrm{wt} \%)$ fiber content. Figure 20 shows the fractured surface of $5 \mathrm{wt} \%$ of fiber coated with epoxy at a magnification of 50X. As can be perceived from this figure, the fibers are not evenly distributed and the bonding with matrix is low which leads reduced strength. Figure 21 shows the fractured surface of 15 wt $\%$ fiber composite without coating of epoxy at a magnification of 500X. As can be seen due to high fiber content clusters of fibers are formed. The interaction between the matrix and fibers is reduced and all fibers 
do not bond with matrix instead forming clusters of fiber leading to reduced tensile strength in comparison to coated material of same wt $\%$. This formation of clusters leads to accumulation of fibers in the matrix; thereby, reducing the UTS. Figure 22 shows the fractured surface of $10 \mathrm{wt} \%$ fiber composite without coating at a magnification of $100 \mathrm{X}$. The surface is not so good and the fibers are not arranged in a proper way, so that the tensile strength is reduced in comparison to coated material of same wt $\%$. Figure 23 shows the fractured surface of $5 \mathrm{wt} \%$ fiber composite with coating at a magnification of $100 \mathrm{X}$. The fiber content is very low (clearly evident from the image) which makes the bonding amongst fibers and matrix weak. Hence, the tensile strength in comparison to coated material is low.

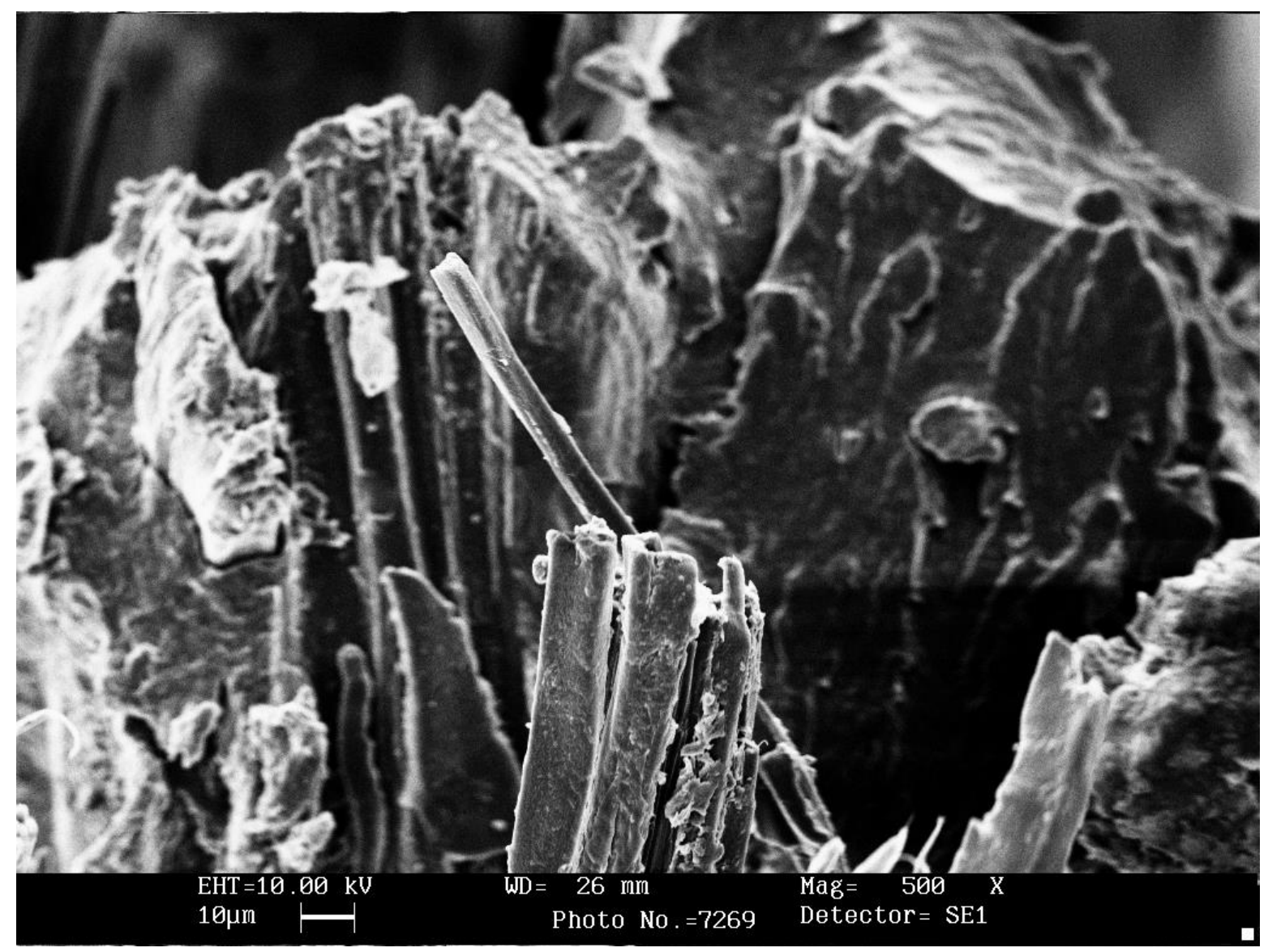

Fig. 16. SEM for (15\% jute fiber by weight) composite material with coating at $500 \mathrm{X}$ 


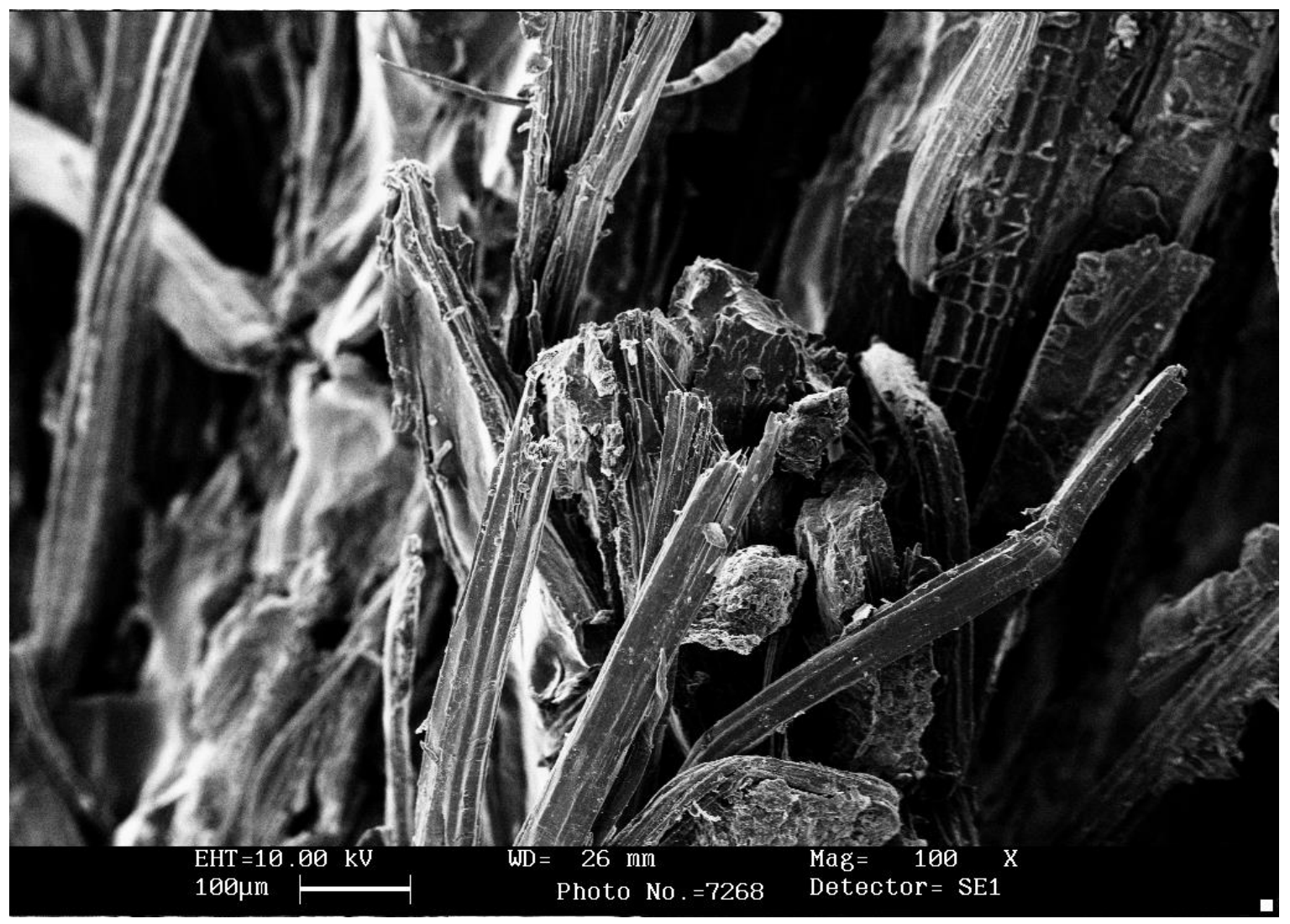

Fig. 17. SEM for ( $15 \%$ jute fiber by weight) composite material with coating at $100 \mathrm{X}$

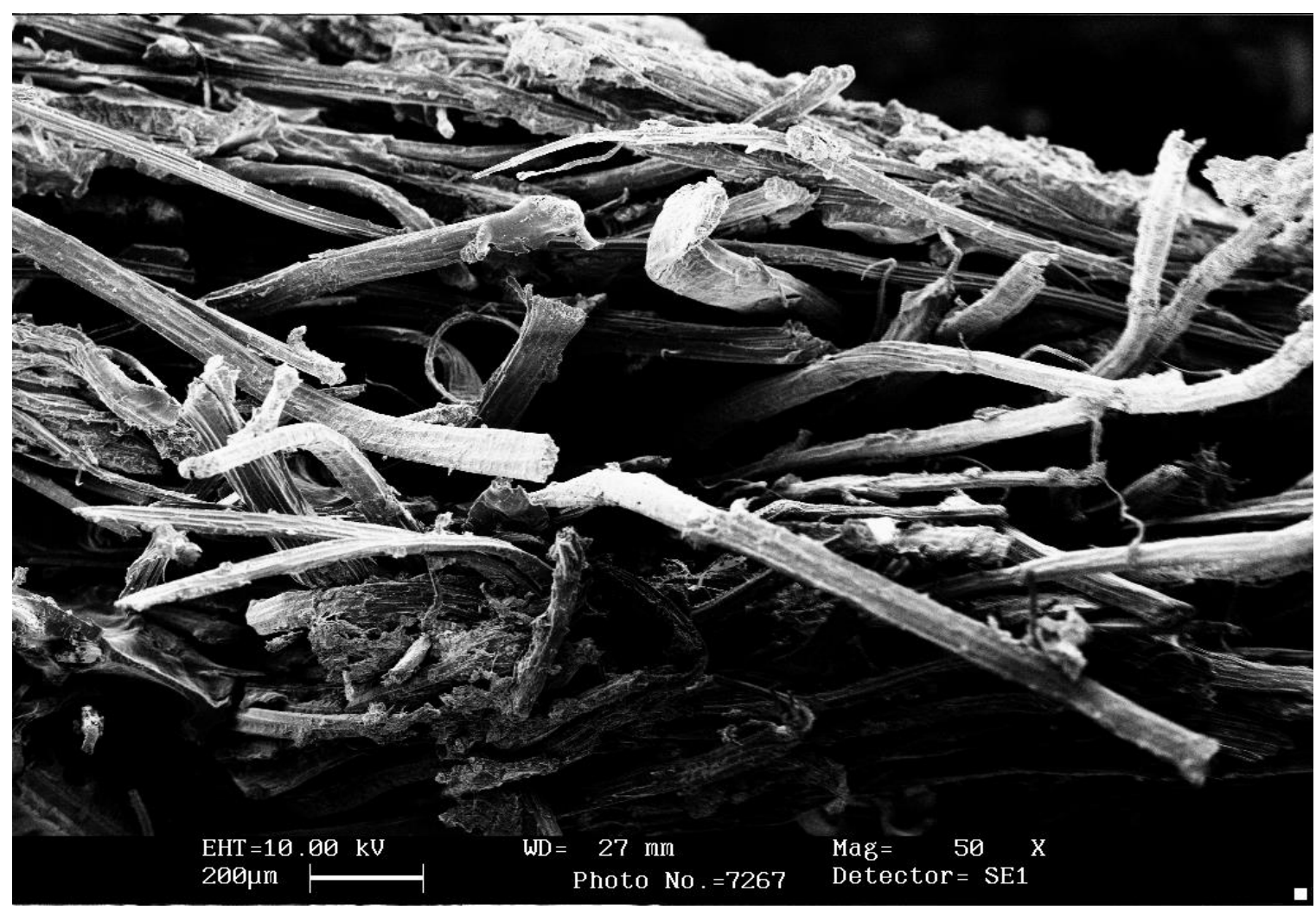

Fig. 18. SEM for (15\% jute fiber by weight) composite material with coating at $50 \mathrm{X}$ 


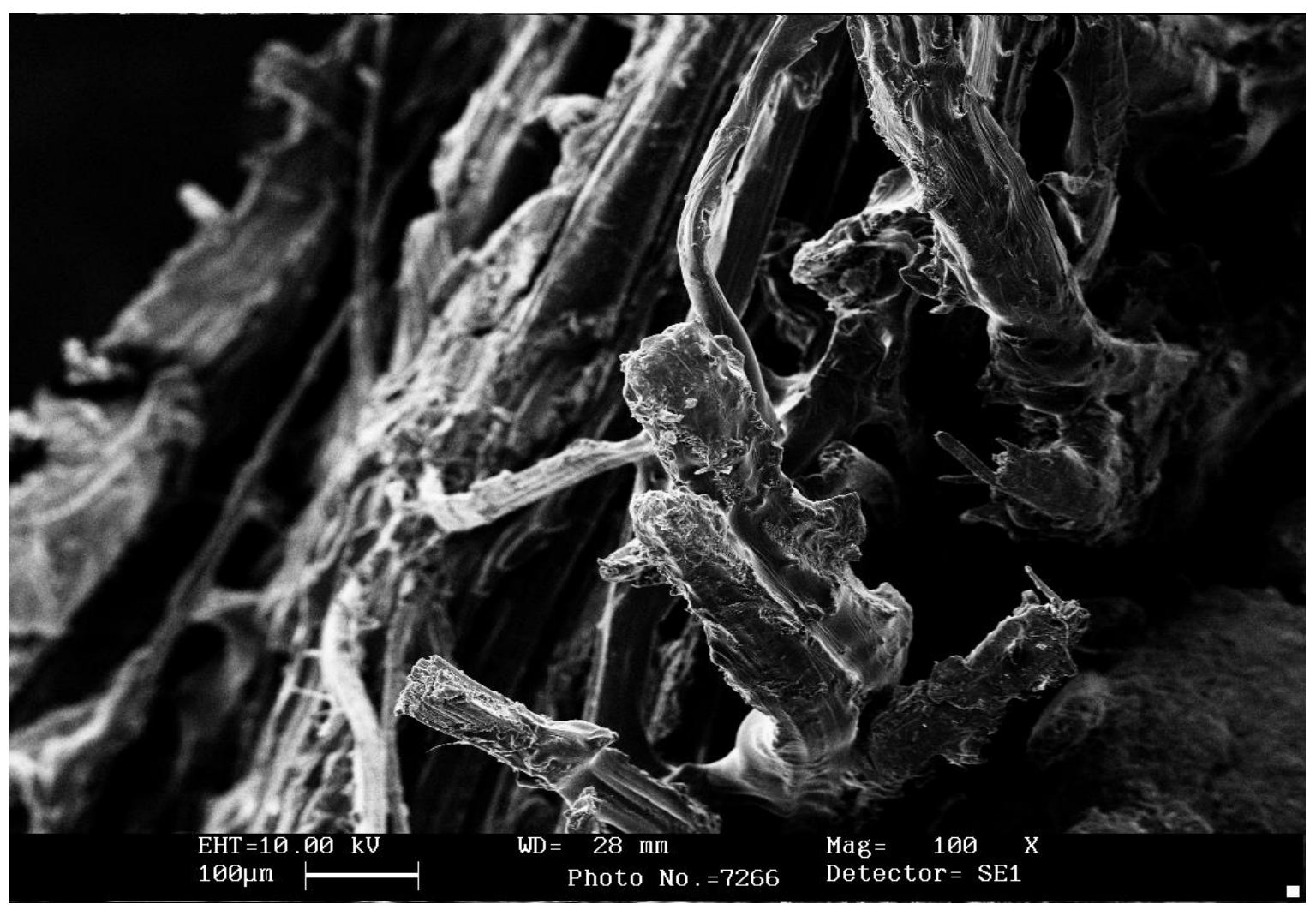

Fig. 19. SEM for (10\% jute fiber by weight) composite material with coating

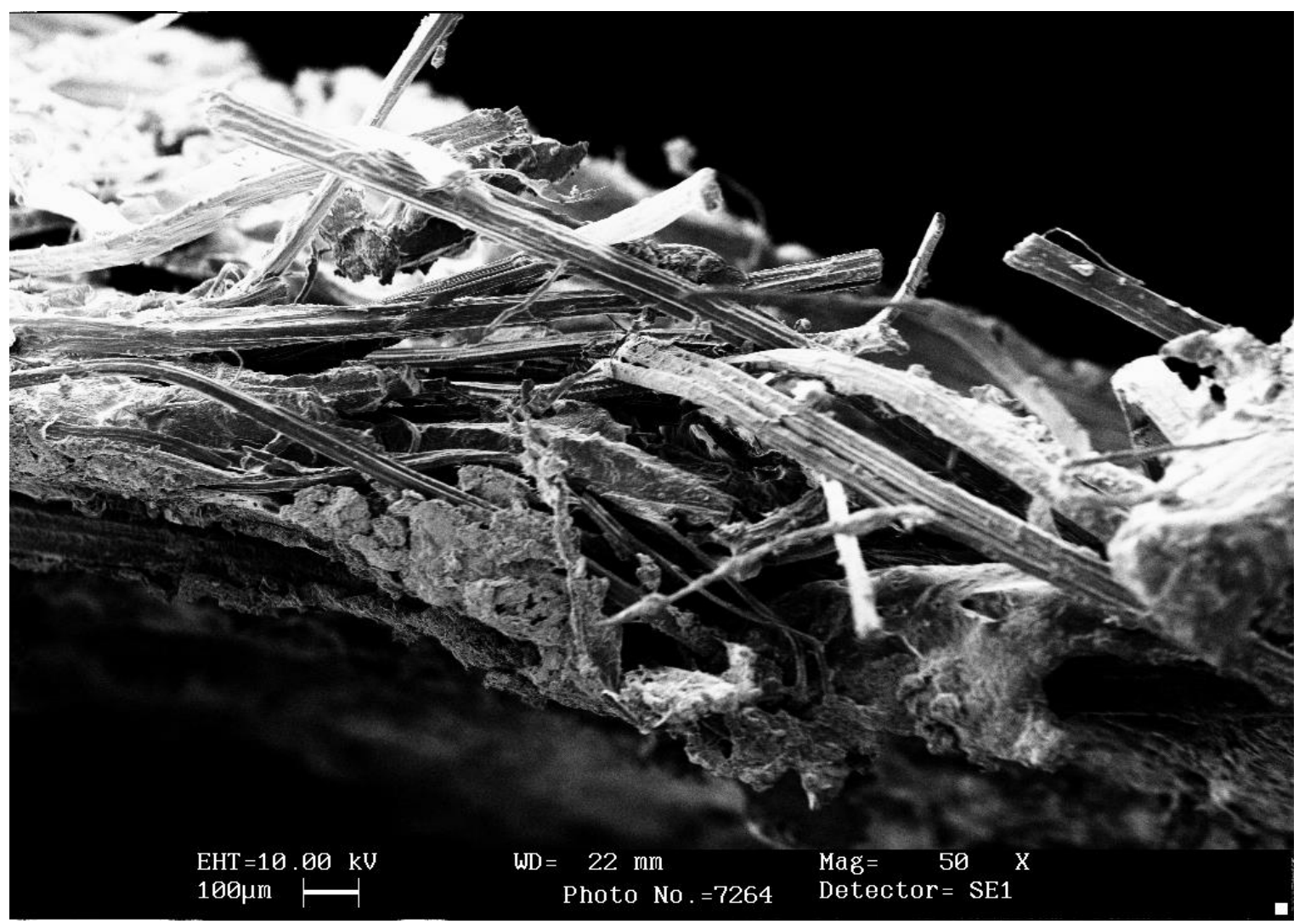

Fig. 20. SEM for (5\% jute fiber by weight) composite material with coating 


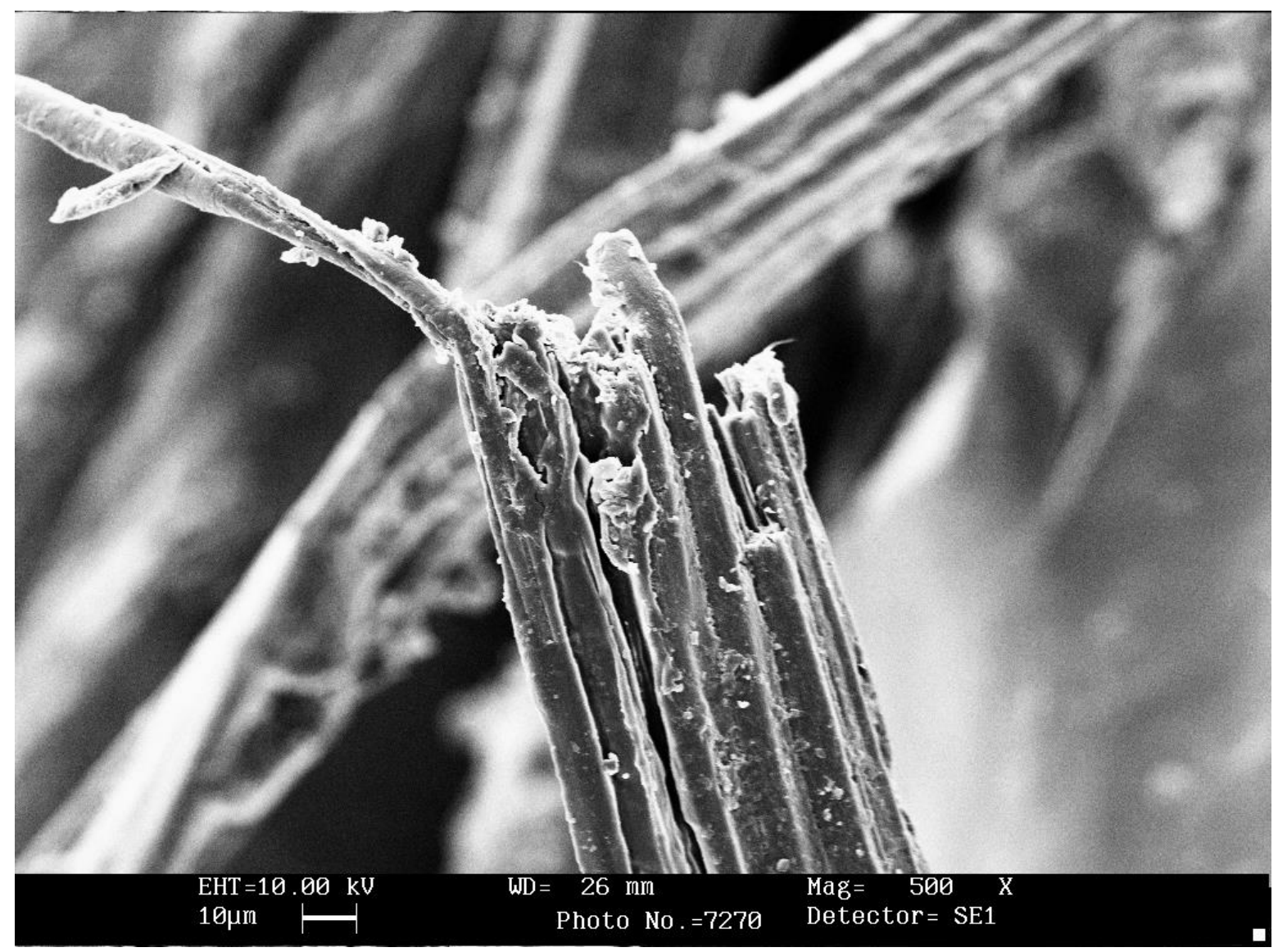

Fig. 21. SEM for (15\% jute fiber by weight) composite material without coating

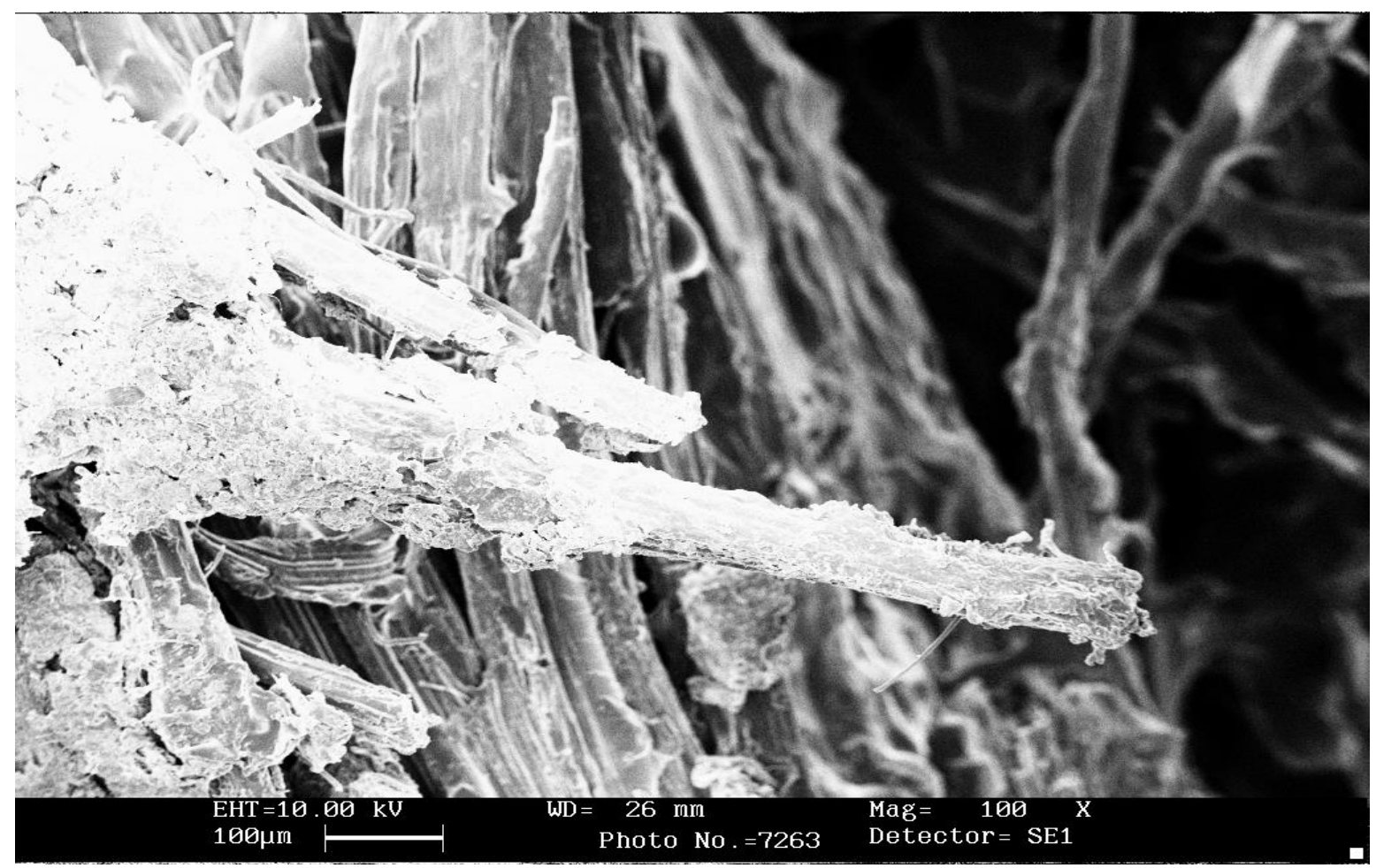

Fig. 22. SEM for (10\% jute fiber by weight) composite material without coating 


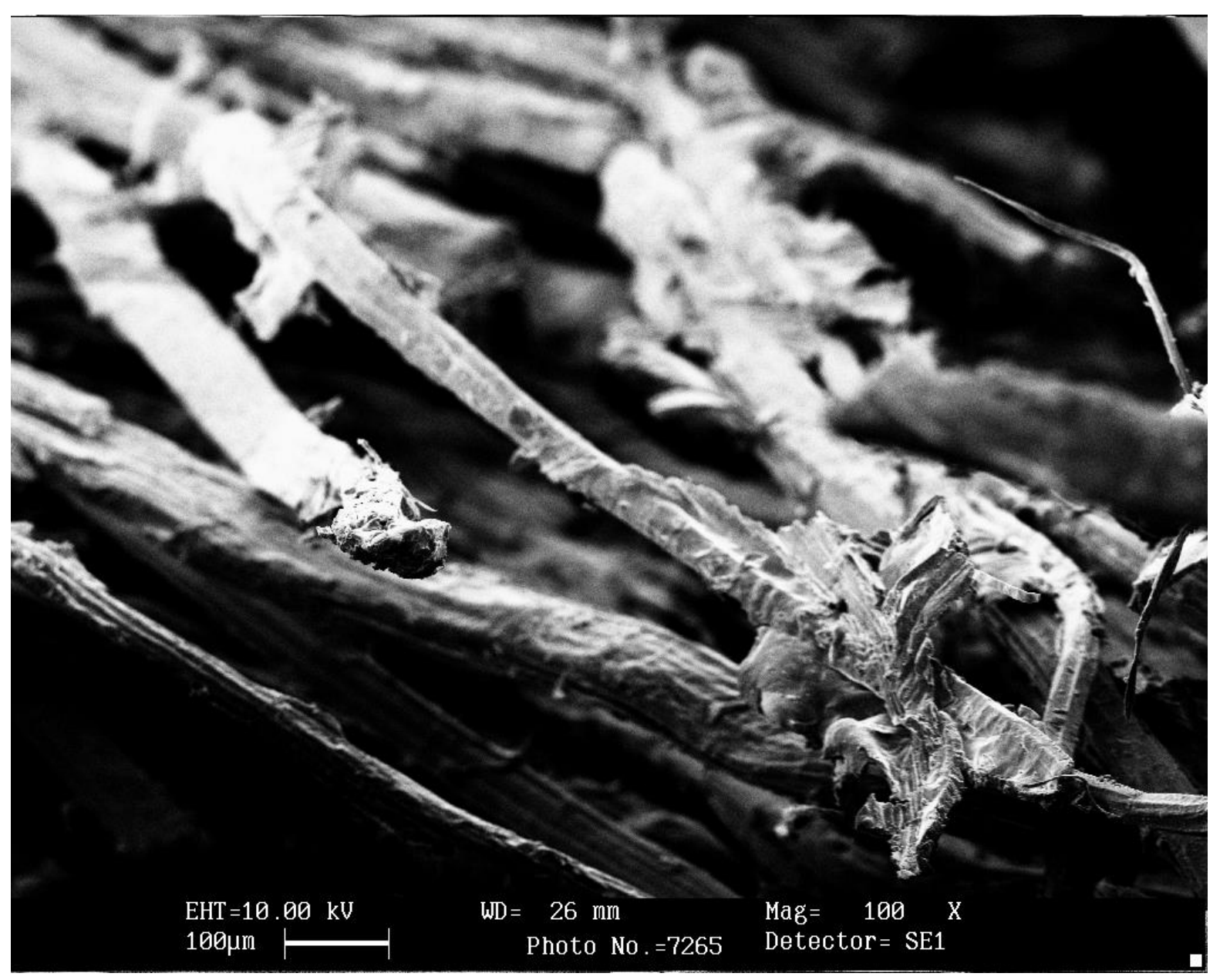

Fig. 23. SEM for (5\% jute fiber by weight) composite material without coating

\subsection{Thermal Analysis}

Thermal analysis has been done for the sample with epoxy coating containing $15 \%$ jute fiber by weight. For thermal analysis, the samples were prepared in powder form by crushing them and the weight of samples were nearly $10.44 \mathrm{mg}$. The base material was alumina powder, which was mixed with composite samples in equal amount and the medium in which the tests were conducted was air flowing at $200 \mathrm{~mL} / \mathrm{min}$. The rate of change of temperature was $10^{\circ} \mathrm{C} / \mathrm{min}$ and range of temperature was room temperature to $250^{\circ} \mathrm{C}$. Figure 24 shows the thermo gram of starch-jute fiber based composite coated with epoxy. Decomposition of this material has been accomplished at $181^{\circ} \mathrm{C}$. The rate of decomposition of the material is $109 \mu \mathrm{g} / \mathrm{min}$. Prior to 
$150^{\circ} \mathrm{C}$, the weight loss of $6.5 \%$ may be attributed to the expulsion of the moisture, low molecular mass molecules and volatile matter associated with the material. In the initial stage of decomposition material absorbs energy (upto $50^{\circ} \mathrm{C}$ ) and after that it releases energy as revealed by the DTA curve. The decomposition of the material has been concluded at $252^{\circ} \mathrm{C}$ leaving the material $78.83 \%$ of the initial weight.

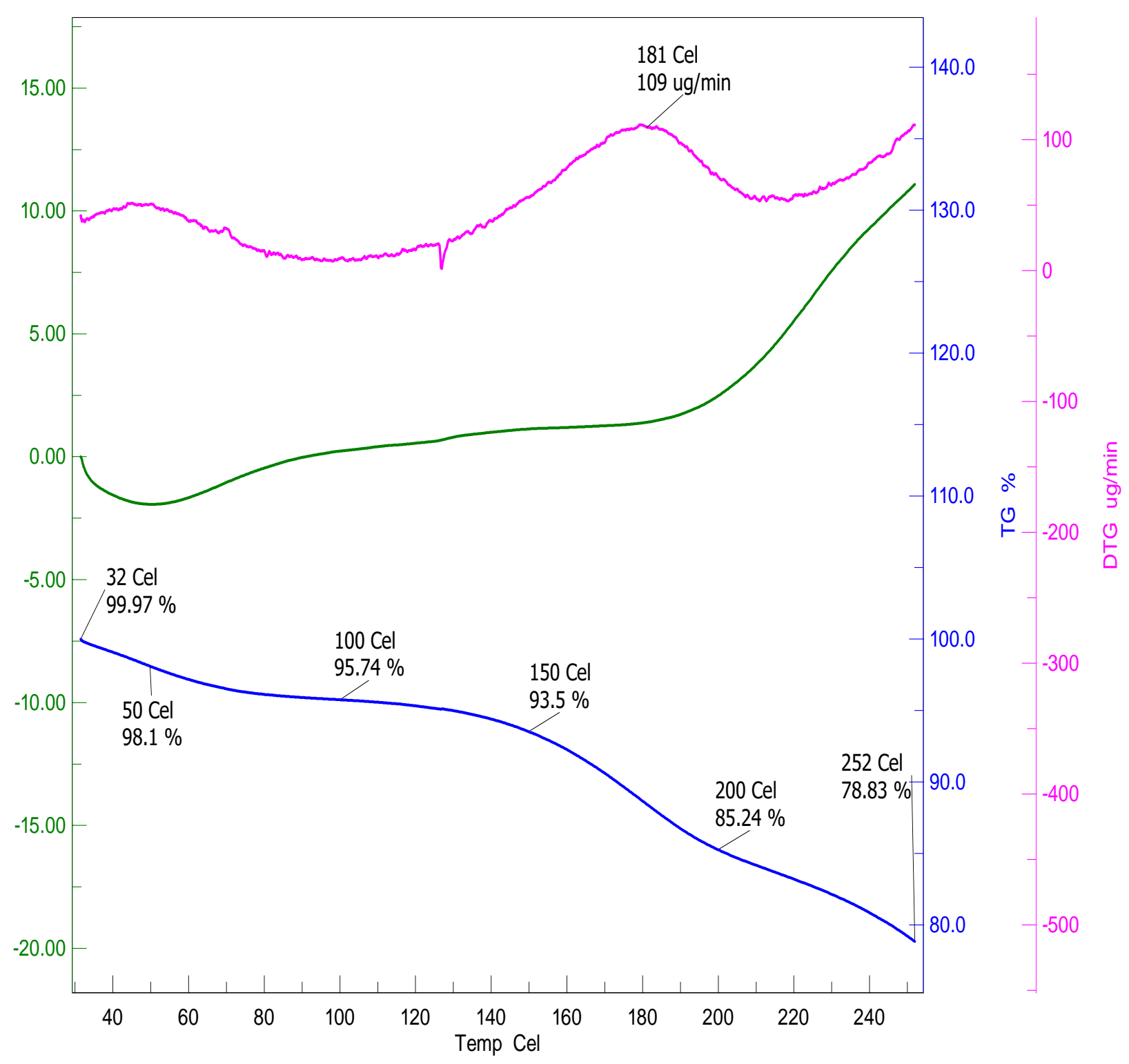

Fig. 24. Thermal analysis of coated sample (15\% fiber by weight) 


\section{Conclusions}

These experimental investigations on jute fiber filled starch bio-composite have led to the following conclusions:

1. Successful fabrication of jute fiber filled starch composite with hand lay-up technique followed by compression is possible.

2. Addition of jute fiber to the starch matrix has improved its UTS. Highest tensile strength was shown by composite containing $15 \%$ fiber by weight. The prepared composite has very low density and is light weight.

3. The green composite prepared has very high water absorption due to highly hydrophilic character of both jute fiber and starch. With increasing fiber content, the water absorption rises gradually and composite containing highest fiber content shows maximum water absorption.

4. Coating the prepared composite with a thin layer of epoxy further enhances the UTS and also reduces the water absorption by a large amount.

5. Through SEM, we could actually see the fibers dispersion in the matrix and their bonding with it. At higher wt\%, fibers form clusters and affect the bonding; and also reveal the composite failure due to fiber pull out and splitting of fiber increases.

6. Thermal analysis reveals that the decomposition of the material is achieved at $181^{\circ} \mathrm{C}$ and the maximum rate of decomposition of the material is $109 \mu \mathrm{g} / \mathrm{min}$.

\section{Acknowledgement}

Financial support from the Department of Science and Technology, New Delhi, India is gratefully acknowledged. 


\section{References}

1. Bledzki, A.K. and Gassan, J., 1999. Composites reinforced with cellulose based fibres. Progress in polymer science, 24(2), pp.221-274.

2. Bogren, K.M., Gamstedt, E.K., Neagu, R.C., Å̊kerholm, M. and LindstroÖm, M., 2006. Dynamic-mechanical properties of wood-fiber reinforced polylactide: experimental characterization and micromechanical modeling. Journal of Thermoplastic Composite Materials, 19(6), pp.613-637.

3. Cao, Y., Shibata, S. and Fukumoto, I., 2006. Mechanical properties of biodegradable composites reinforced with bagasse fibre before and after alkali treatments. Composites part A: Applied science and Manufacturing, 37(3), pp.423-429.

4. Gilfillan, W.N., Nguyen, D.M., Sopade, P.A. and Doherty, W.O., 2012. Preparation and characterisation of composites from starch and sugar cane fibre. Industrial Crops and Products, 40, pp.45-54.

5. Gon, D., Das, K., Paul, P. and Maity, S., 2012. Jute composites as wood substitute. International Journal of Textile Science, 1(6), pp.84-93.

6. Gujjala, R., Ojha, S., Acharya, S.K. and Pal, S.K., 2014. Mechanical properties of woven jute-glass hybrid-reinforced epoxy composite. Journal of Composite Materials, 48(28), pp.3445-3455.

7. Liu, L., Yu, J., Cheng, L. and Yang, X., 2009. Biodegradability of poly (butylene succinate) (PBS) composite reinforced with jute fibre. Polymer Degradation and Stability, 94(1), pp.9094.

8. Zhao, Q., Hoa, S.V. and Gao, Z.J., 2011. Thermal stresses in rings of thermoplastic composites made by automated fiber placement process. Science and Engineering of Composite Materials, 18(1-2), pp.35-49.

9. Gassan, J. and Bledzki, A.K., 1999. Possibilities for improving the mechanical properties of jute/epoxy composites by alkali treatment of fibres. Composites Science and Technology, 59(9), pp.1303-1309.

10. Gowda, T.M., Naidu, A.C.B. and Chhaya, R., 1999. Some mechanical properties of untreated jute fabric-reinforced polyester composites. Composites Part A: applied science and manufacturing, 30(3), pp.277-284. 
11. Mohanty, A.K., Khan, M.A. and Hinrichsen, G., 2000. Influence of chemical surface modification on the properties of biodegradable jute fabrics-polyester amide composites. Composites Part A: Applied Science and Manufacturing, 31(2), pp.143-150.

12. De Albuquerque, A.C., Joseph, K., de Carvalho, L.H. and d'Almeida, J.R.M., 2000. Effect of wettability and ageing conditions on the physical and mechanical properties of uniaxially oriented jute-roving-reinforced polyester composites. Composites Science and Technology, 60(6), pp.833-844.

13. Ray, D., Sarkar, B.K., Rana, A.K. and Bose, N.R., 2001. Effect of alkali treated jute fibres on composite properties. Bulletin of materials science, 24(2), pp.129-135.

14. Khondker, O.A., Ishiaku, U.S., Nakai, A. and Hamada, H., 2005. Fabrication mechanical properties of unidirectional jute/PP composites using jute yarns by film stacking method. Journal of Polymers and the Environment, 13(2), pp.115-126.

15. Cabral, H., Cisneros, M., Kenny, J.M., Vazquez, A. and Bernal, C.R., 2005. Structureproperties relationship of short jute fiber-reinforced polypropylene composites. Journal of Composite Materials, 39(1), pp.51-65.

16. Corrales, F., Vilaseca, F., Llop, M., Girones, J., Mendez, J.A. and Mutje, P., 2007. Chemical modification of jute fibers for the production of green-composites. Journal of Hazardous Materials, 144(3), pp.730-735.

17. Vilaseca, F., Mendez, J.A., Pelach, A., Llop, M., Canigueral, N., Girones, J., Turon, X. and Mutje, P., 2007. Composite materials derived from biodegradable starch polymer and jute strands. Process Biochemistry, 42(3), pp.329-334.

18. Akil, H.M., Cheng, L.W., Ishak, Z.M., Bakar, A.A. and Rahman, M.A., 2009. Water absorption study on pultruded jute fibre reinforced unsaturated polyester composites. Composites Science and Technology, 69(11-12), pp.1942-1948.

19. Das, K., Ray, D., Bandyopadhyay, N.R., Sahoo, S., Mohanty, A.K. and Misra, M., 2011. Physico-mechanical properties of the jute micro/nanofibril reinforced starch/polyvinyl alcohol biocomposite films. Composites Part B: Engineering, 42(3), pp.376-381.

20. Thitithanasarn, S., Yamada, K., Ishiaku, U.S. and Hamada, H., 2012. The effect of curative concentration on thermal and mechanical properties of flexible epoxy coated jute fabric reinforced polyamide 6 composites. Open Journal of Composite Materials, 2(04), p.133. 
21. Hossain, M.R., Islam, M.A., Van Vuurea, A. and Verpoest, I., 2013. Tensile behavior of environment friendly jute epoxy laminated composite. Procedia Engineering, 56, pp.782-788. 22. Hojo, T., Xu, Z., Yang, Y. and Hamada, H., 2014. Tensile properties of bamboo, jute and kenaf mat-reinforced composite. Energy Procedia, 56, pp.72-79.

23. Verma, A., Gaur, A. and Singh, V.K., 2017. Mechanical Properties and Microstructure of Starch and Sisal Fiber Biocomposite Modified with Epoxy Resin. Materials Performance and Characterization, 6(1), pp.500-520.

\section{4. https://en.wikipedia.org/wiki/Starch}

25. Roul, C., 2009. The international jute commodity system. Northern Book Centre.

\section{6. https://en.wikipedia.org/wiki/Glycerol}

\section{7. https://en.wikipedia.org/wiki/Citric_acid}

28. Agarwal, M., Arif, M., Bisht, A., Singh, V.K. and Biswas, S., 2015. Investigation of toughening behavior of epoxy resin by reinforcement of depolymerized latex rubber. Science and Engineering of Composite Materials, 22(4), pp.399-404.

29. Cibatul Limited, P.O. Atul 396 020, Dist. Valsad, Gujarat.

30. Singh, V.K. and Gope, P.C., 2010. Silica-styrene-butadiene rubber filled hybrid composites: experimental characterization and modeling. Journal of Reinforced Plastics and Composites, 29(16), pp.2450-2468.

31. Verma, A. and Singh, V. K., "Mechanical, Microstructural and Thermal Characterization of Epoxy-Based Human Hair-Reinforced Composites," Journal of Testing and Evaluation, https://doi.org/10.1520/JTE20170063. ISSN 0090-3973.

32. ASTM D638-14: Standard Test Method for Tensile Properties of Plastics, Annual Book of ASTM Standards, ASTM International.

33. ASTM D3039/D3039M-14: Standard Test Method for Tensile Properties of Polymer Matrix Composite Materials, Annual Book of ASTM Standards, ASTM International.

34. Liu, W., Hoa, S.V. and Pugh, M., 2008. Water uptake of epoxy-clay nanocomposites: Experiments and model validation. Composites Science and Technology, 68(9), pp.2066-2072. 
35. Chaudhary, A.K., Gope, P.C., Singh, V.K., Suman, A.R. and Verma, A., 2014. Thermal analysis of epoxy based coconut fiber-almond shell particle reinforced biocomposites. Advances in Manufacturing Science and Technology, 38(2).

36. Kaboorani, A., 2009. Thermal properties of composites made of heat-treated wood and polypropylene. Journal of composite materials, 43(22), pp.2599-2607.

37. Singh, V.K., 2015. Mechanical behavior of walnut (Juglans L.) shell particles reinforced bio-composite. Science and Engineering of Composite Materials, 22(4), pp.383-390.

38. Chaudhary, A.K., Gope, P.C. and Singh, V.K., 2015. Water absorption and thickness swelling behavior of almond (Prunus amygdalus L.) shell particles and coconut (Cocos nucifera) fiber hybrid epoxy-based biocomposite. Science and Engineering of Composite Materials, 22(4), pp.375-382.35 